\title{
Congenital mesoblastic nephroma fifty years after its recognition: A narrative review
}

\begin{tabular}{|c|c|}
\hline Journal: & Pediatric Blood \& Cancer \\
\hline Manuscript ID & PBC-16-1071.R1 \\
\hline Wiley - Manuscript type: & Review \\
\hline Date Submitted by the Author: & 06-Dec-2016 \\
\hline Complete List of Authors: & $\begin{array}{l}\text { Gooskens, Saskia; Princess Máxima Center for Pediatric Oncology, Utrecht, } \\
\text { The Netherlands; Erasmus MC-Sophia Children's Hospital, Department of } \\
\text { Pediatric Oncology/Hematology } \\
\text { Houwing, Maite; Princess Máxima Center for Pediatric Oncology, Utrecht, } \\
\text { The Netherlands; Erasmus MC-Sophia Children's Hospital, Department of } \\
\text { Pediatric Oncology/Hematology } \\
\text { Vujanic, Gordan; Department of Cellular Pathology, University Hospital of } \\
\text { Wales/Cardiff, University School of Medicine, Heath Park, Cardiff, United } \\
\text { Kingdom } \\
\text { Dome, Jeffrey; Children's National Medical Center, Oncology } \\
\text { Diertens, Tessa; Princess Máxima Center for Pediatric Oncology, Utrecht, } \\
\text { The Netherlands } \\
\text { Coulomb-L'herminé, Aurore; AP-HP - Groupe Hospitalier Armand } \\
\text { Trousseau - La Roche-Guyon, Service d'Anatomie et Cytologie } \\
\text { Pathologiques } \\
\text { Godzinski, Jan; Marciniak Hospital, Pediatric Surgery } \\
\text { Pritchard Jones, Kathy ; 7. Cancer Section, University College London } \\
\text { Institute of Child Health, London, UK } \\
\text { Graf, Norbert; Saarland University, Department of Pediatric Oncology and } \\
\text { Hematology } \\
\text { Van den Heuvel, Marry; Princess Máxima Center for Pediatric Oncology, } \\
\text { Utrecht, The Netherlands }\end{array}$ \\
\hline Keywords: & $\begin{array}{l}\text { congenital mesoblastic nephroma, infancy, clinical characteristics, } \\
\text { histology, genetics, treatment, outcome, review, renal tumor }\end{array}$ \\
\hline
\end{tabular}


1 Congenital mesoblastic nephroma fifty years after its recognition: A narrative review

2 Running head: Review on congenital mesoblastic nephroma

3

4
S.L. Gooskens* ${ }^{1,2}$ and M.E. Houwing* ${ }^{1,2}$, G.M. Vujanic ${ }^{3}$, J.S. Dome ${ }^{4}$, T. Diertens ${ }^{1}$, A. Coulomb-Herminé ${ }^{5}$, J. Godzinski ${ }^{6}$, K. Pritchard-Jones ${ }^{7}$, N. Graf ${ }^{8}$ and M.M. van den HeuvelEibrink $^{1}$

1. Princess Máxima Center for Pediatric Oncology, Utrecht, The Netherlands

2. Department of Pediatric Oncology, Erasmus MC - Sophia Children's Hospital, Rotterdam, The Netherlands

3. Department of Cellular Pathology, University Hospital of Wales/Cardiff, University School of Medicine, Heath Park, Cardiff, United Kingdom

4. Division of Oncology, Children's National Health System, Washington DC, USA

5. Department of Pathology, Hopitaux Universitaires Est Parisien, Trousseau La RocheGuyon, Paris, France

6. Department of Emergency Medicine, Medical University of Wroclaw, and Department of Pediatric Surgery, Marciniak Hospital, Wroclaw, Poland

7. Cancer Section, University College London Institute of Child Health, London, UK

8. Department of Pediatric Hematology and Oncology, Saarland University, Saarbrucken, Germany

* These authors contributed equally to this work

Correspondence: Marry M. van den Heuvel-Eibrink

Princess Maxima Center for Pediatric Oncology/Hematology Lundlaan 6, 3584 EA, Utrecht, The Netherlands +31889727000 m.m.vandenheuvel-eibrink@prinsesmaximacentrum.nl

Abstract word count: 101

Main text word count: 3467

No of tables: 2

No of figures: 2

No of supplemental tables: 6

Keywords: congenital mesoblastic nephroma; infancy; clinical characteristics; histology; genetics; treatment; outcome; review; renal tumor

Abbreviations key

\begin{tabular}{|l|l|}
\hline CMN & Congenital mesoblastic nephroma \\
\hline BWS & Beckwith-Wiedemann syndrome \\
\hline AV & Actinomycin and vincristine \\
\hline
\end{tabular}




\section{Abstract}

40 Congenital mesoblastic nephroma $(\mathrm{CMN})$ is a rare pediatric renal tumor with low malignant 41 potential that most commonly occurs early in infancy. Treatment strategies are based on the few 42 published CMN series, while a significant number of CMN patients have been described in case 43 reports. The aim of this narrative review was to create an up-to-date overview of the literature. 44 Complete surgical removal is curative in most cases. The risk of treatment-related mortality 45 (both surgery- and chemotherapy-related) is relatively high in the first weeks of life, indicating 46 that these young patients deserve special attention with respect to timing and type of treatment. 47 


\section{Introduction}

49 Congenital mesoblastic nephroma $(\mathrm{CMN})$ is a rare tumor with low malignant potential, which 50 represents approximately $3 \%$ of all pediatric renal tumors [1-3]. It is the most common renal 51 neoplasm diagnosed in the first month of life [4,5]. CMN is frequently recognized before or at 52 time of birth, illustrating the embryonal character of the disease.

53 Bolande was the first to use the term 'congenital mesoblastic nephroma' in 1967, though decades 54 earlier this tumor was already described using different terminologies including fetal renal 55 hamartoma and leiomyomatous renal hamartoma [3,6-9]. The histological classification of CMN 56 includes three subtypes, i.e. the classic, cellular and mixed type [10-12]. Recurrent genetic 57 aberrations described in CMN include somatic trisomy 11 and $\mathrm{t}(12 ; 15)(\mathrm{p} 13 ; \mathrm{q} 25)$, resulting in a 58 fusion of ETV6 and NTRK3 [13,14].

59 The vast majority of CMN patients seems to present with local disease. Complete nephrectomy 60 is considered the standard of care for children with $\mathrm{CMN}$, although use of adjuvant 61 chemotherapy and even radiotherapy has been reported $[2,15,16]$. These treatment strategies are 62 mainly based on the few published CMN series with substantial numbers. A significant number 63 of CMN patients have been described in case reports and to date a comprehensive review is not 64 available. The aim of this narrative review was to gain insight into the clinical characteristics, 65 histological subtypes, genetic aberrations, treatment modalities and outcome of patients with $66 \mathrm{CMN}$, in order to develop future treatment strategies.

\section{Methods}

69 For this review, databases of PubMed, Embase, Web of Science, Scopus and Google scholar were searched using search terms "mesoblastic nephroma", "mesoblast" within 3 words of "nephrom", "non-Wilms" or "not-Wilms" (mesoblastic nephroma*[tw] OR (mesoblast*[tw]

72 NEAR/3 nephrom*[tw])) OR non-Wilms*[tw] OR not-Wilms*[tw]). After removal of double 73 articles, 984 articles published before 1 December 2015 remained (Fig 1). Thirteen articles were 74 added after hand searching. Articles were selected on the basis of title and abstract by two 75 independent reviewers (S.L.G. and T.D.) (Fig 1). To be eligible for inclusion, a study had to (1) 76 contain well-described CMN patients $<18$ years of age, (2) be an original article, (3) be reported 77 after the study by Bolande et al (1967), (4) be written in English language and (5) be available in 78 full-text. In case of doubt about the histological diagnosis or in case the tumor was described 
79 under a different name, the paper was reviewed extensively by an expert pathologist (G.J.V.)

80 before inclusion in the current review.

\section{Results}

83 A total of 200 articles met the inclusion criteria (Fig. 1). Of these, 25 articles reported series of

$84 \geq 10$ patients which included 628 patients in total (Table 1, Supplemental Table S1). Where more

85 than one paper reported on the same or overlapping cohorts, the report with the most detailed

86 information on the largest number of individuals was used; eventually 12 non-overlapping series

87 including 306 patients were selected for the analysis in this review (Table 1).

88 In addition to these series, 174 case reports described 270 cases in total (Supplemental Table S2).

89 Data of these case reports were only included in the analysis of this review if they provided well

90 documented data and relevant additional information, such as the correlation between genotype

91 and histology and characteristics of stage III or relapsed CMN patients.

\section{Clinical characteristics}

94 Median age at diagnosis ranged from 0 days (newborn) - 2.3 months (median age $\leq 1$ month in $9563 \%$ of series) and overall age ranged from prenatal - 3.8 years (Table 1). Prenatal detection of 96 the tumor was reported in $16 \%$ of the patients [15,17-19]. The male to female ratio was $1.5: 1$ 97 (Table 1). The most commonly reported presenting symptom was an abdominal mass, described 98 in $76 \%$ of the cases (Table 1). Other repeatedly reported symptoms were hypertension (19\%) and 99 hematuria (11\%) (Table 1). Case reports additionally reported polyhydramnios in 40/270 cases 100 (15\%), hypercalcemia in $12 / 270$ cases (4\%) and hyperreninemia in $3 / 270$ cases (1\%) 101 (Supplemental Table S2). Both hypercalcemia and hyperreninemia completely resolved with 102 removal of the tumor in all cases [5,20-34].

103 Congenital anomalies were reported in 11 patients described in series; genitourinary anomalies 104 were described in 6 patients, gastrointestinal malformations in 2 patients, polydactyly in 1 105 patient, hydrocephalus in 1 patient and 1 patient was described to be diagnosed with the 106 Beckwith-Wiedemann syndrome (BWS) [2,15,18,35]. In case reports, 2 additional patients with 107 BWS were diagnosed with CMN $[5,36]$. 


\section{Pathology}

$110 \mathrm{CMN}$ is classified into three histological subtypes: classic, cellular and mixed type. Classical 111 type $\mathrm{CMN}$ shows a leiomyomatous pattern resembling infantile fibromatosis composed of 112 interlacing bundles of spindle cells and low mitotic activity, no capsule, infiltrative growth into 113 the renal parenchyma and/or perirenal fat, and entrapped islands of parenchyma [37]. The 114 cellular type, identical to infantile fibrosarcoma, shows dense cellularity, a strong 115 hemangiopericytous vascular pattern and a high mitotic activity but less infiltrative growth into 116 the renal parenchyma [10,37]. Mixed type CMN shows a mixture of these two patterns in any 117 proportion [37]. Information on histological subtype was available for 231 patients; the classic 118 type occurred in 91 patients (39\%), the cellular type in 96 patients (42\%), the mixed type in 23 119 patients (10\%) and classic/mixed type (no discrimination) in 21 patients (9\%) (Table 1). In three 120 series a significant difference in age between classic (median age ranging between 6-17 days) 121 and cellular type CMN (median age ranging between 3.7-5 months) was reported [15,16,19]. The 122 median age of mixed type CMN was described in only one series, i.e. 1.9 months [16].

123 Information on stage was available for 251 patients; stage I/II disease was found in 208 patients 124 (83\%) and stage III disease in 42 patients (17\%) (Table 1). Reasons for stage III disease were 125 positive surgical margins $(n=13)$, tumor rupture $(n=12)$ or a combination of positive surgical 126 margins and tumor rupture $(\mathrm{n}=11)$, while in 8 patients the reason for stage III was unknown $127[2,10,15-18,38-40]$. One patient was described to have stage IV disease because of 'suspected' 128 malignant cells in the bone marrow, however these cells were not histologically proven to be 129 CMN cells, so we consider this case not being stage IV [35]. In case reports, another case was described to have stage IV disease at diagnosis (lesions in the right tibia on CT scan, however no 131 histological confirmation available) [41]. Bilateral (stage V) disease has never been reported. 132 Stage in relation to histological type is presented in Figure 2.

133 Data on immunohistochemistry were described in one series, showing immunoreactive renin 134 (intense staining in vessels within areas of the trapped cortex) in 10/12 studied cases [38,39]. 135 Case reports provided information on immunohistochemical staining in 53 cases. In these cases, 136 in total 27 different immunohistochemical markers were used. No marker specific for CMN 137 could be identified (Supplemental Table S3).

\section{Genetics}


140 The most commonly reported genetic aberrations in $\mathrm{CMN}$ are $\mathrm{t}(12 ; 15)(\mathrm{p} 13 ; \mathrm{q} 25)$, leading to a 141 fusion of the genes ETV6 and NTRK3, and trisomy 11 (both somatic). In Table 2, information on 142 stage, histological type and outcome is provided for cases harboring $\mathrm{t}(12 ; 15)(\mathrm{p} 13 ; \mathrm{q} 25)$ and cases 143 harboring trisomy 11. In series, $\mathrm{t}(12 ; 15)(\mathrm{p} 13 ; \mathrm{q} 25)$ and trisomy 11 were identified in 29\% and $14454 \%$ of the analyzed cases, respectively $[13,18,19,40]$. No clear relation between stage and 145 genetic subtype could be identified. Both genetic aberrations occurred in mixed/cellular type $146 \mathrm{CMN}$ only, and never in the classic type of CMN (Table 2). Median ages of patients harboring $147 \mathrm{t}(12 ; 15)(\mathrm{p} 13 ; \mathrm{q} 25)$ and patients harboring trisomy 11 were both 1 month.

148 Other recurrently reported genetic aberrations in $\mathrm{CMN}$ (in case reports) are trisomies $8(\mathrm{n}=9), 17$ $149(\mathrm{n}=4), 20(\mathrm{n}=4), 7(\mathrm{n}=3), 10(\mathrm{n}=3), 18(\mathrm{n}=2), 2(\mathrm{n}=2)$ and $9(\mathrm{n}=2)$ (Supplemental Table S2); all 150 identified aberrations only occurred in mixed/cellular type CMN.

\section{Treatment}

153 Treatment details were available for 263 patients. Pre-operative chemotherapy was administered 154 in only 9 patients, consisting of actinomycin and vincristine (AV) in 8 patients and unknown 155 type of treatment in one patient $[15,16,18]$. Information on response to pre-operative 156 chemotherapy was described in 6 cases; 5 cases treated with AV showed a reduction in tumor 157 size of at least $30 \%$ and one case treated with AV had a significant increase in tumor size, but 158 histology at time of surgery showed $80 \%$ necrosis $[15,16]$.

159 All patients underwent surgery (179 complete nephrectomy, 6 partial nephrectomy (re-excision $160 \mathrm{n}=3$ ), 77 unknown type of surgery), except for one patient who died before surgery could be 161 applied.

162 Post-operative chemotherapy had been administered in 50 patients, consisting of AV in 21 cases, 163 actinomycin alone in 11 cases, AV and doxorubicin in 3 cases, AV and cyclophosphamide in 1 164 case, etoposide/cyclophosphamide/doxorubicin/carboplatin in one case and in 13 cases type of 165 post-operative chemotherapy was unknown [2,10,15,16,18,35,38,39,42]. Radiotherapy was 166 applied in nine cases $[2,10,15,35]$.

\section{Outcome}

169 Information on outcome was available for 276 patients described in series (Table 1). Of these, 170264 patients survived (96\%) and 12 patients died (4\%). Causes of death in these 12 patients were 
171 disease-related in 5 cases and treatment-related in 7 cases ( 5 surgery-related, 2 chemotherapy172 related) (Supplemental Table S4). Median age at diagnosis of patients who died of disease was 6 173 months, while median age at diagnosis of patients who died of treatment-related causes was 0 174 days (newborn). Surgery-related causes of death included post-operative sepsis ( $\mathrm{n}=2)$, post175 operative necrotizing enterocolitis $(n=1)$, intra-operative bleeding $(n=1)$ and 'not specified' $176(\mathrm{n}=1)$. Chemotherapy-related causes of death consisted of severe neutropenia and sepsis $(\mathrm{n}=2)$.

177 Information on occurrence of relapse was available for all 306 patients described in series. 178 Relapses occurred in 12 patients (4\%) (9 local, 2 metastatic in lung and bone, 1 location 179 unknown) (Supplemental Table S5). The histological subtype was known in 11 relapsed cases (8 180 cellular, 1 classic, 2 mixed). Information on outcome after relapse was available in 10 cases; 6 181 achieved a second complete remission and 4 patients died of disease (Supplemental Table S5).

Prognostic value of stage, histologic subtype and genetic aberrations

184 Information on outcome according to stage was available for 145 patients described in series. Of 185125 patients with stage I/II disease, 4 patients $(3 \%)$ suffered from a relapse and 6 patients $(5 \%)$ 186 died (3 of treatment-related toxicity and 3 of disease) (Supplemental Table S4 and S5). Of note, 187 only 1 of $100(1 \%)$ stage I/II patients treated with surgery alone, developed a relapse. Of 34 188 patients with stage III disease, 6 patients (18\%) had a relapse (4 cellular, 1 mixed, 1 unknown 189 histology) and 2 patients (11\%) died of tumor progression (both cellular) (Supplemental Table 190 S4 and S5). As this is only a small set of patients, we also analyzed stage III patients as described 191 in case reports. Stage III patients reported in case reports $(n=22)$, together with stage III patients 192 reported in series $(n=34)$ are described in Supplemental Table S6; 15/56 stage III patients (23\%) 193 suffered from a relapse (73\% cellular subtype) and 4/56 patients (6\%) died of disease (all cellular 194 subtype).

195 Information on outcome according to histological subtype was available for 156 patients 196 described in series. Of 74 patients with classic type CMN, 1 patient (1\%) (stage II) had a relapse 197 and another patient (1\%) (stage II) died of surgical complications (Supplemental Table S4 and 198 S5). Of 59 patients with cellular type CMN, 6 patients (10\%) (1 stage I, 1 stage II, 4 stage III) 199 had a relapse and 4 patients (7\%) (1 stage I, 1 stage II and 2 stage III) died of disease 200 (Supplemental Table S4 and S5). Of 23 patients with mixed type CMN, one patient (4\%) (stage 201 III) had a relapse, but was alive after treatment (Supplemental Table S5 and S6). 
202 Outcomes of patients harboring $\mathrm{t}(12 ; 15)(\mathrm{p} 13 ; \mathrm{q} 25)$ and trisomy 11 are described in Table 2.

\section{Discussion}

205 The aim of this narrative review was to present a comprehensive and up-to-date overview of 206 clinical characteristics, optimal treatment strategies and outcome of different histological and 207 genetic subtypes of $\mathrm{CMN}$, thereby serving future treatment guideline development for this rare 208 tumor.

209 Most studies reporting on CMN have not been based on (inter-)national registries. Therefore, the 210 prevalence of $\mathrm{CMN}$ and its histological subtypes is hard to analyze. Large series have suggested 211 that $\mathrm{CMN}$ comprises $3.5-4 \%$ of all pediatric renal tumors, but it is conceivable that perinatal 212 diagnosed cases may have been considered benign, and therefore not have been included in renal 213 tumor registries $[15,16]$. The frequency of the cellular subtype and classic subtype seems to be 214 similar, while the mixed subtype occurs remarkably less often $( \pm 10 \%)[15,16,19]$.

215 CMN most commonly occurs early in infancy and over $15 \%$ of the cases are detected prenatally $216[13,15,16,35,38,39]$. Although $\mathrm{CMN}$ has been reported in 26 adult patients in literature, it 217 remains uncertain whether these cases are real CMN's [43-62]. It is believed that most of these 218 so-called adult mesoblastic nephromas are now recognized to have represented other tumors, 219 such as metanephric stromal tumor, cystic hamartoma of the renal pelvis or mixed epithelial and 220 stromal tumor $[63,64]$. For this reason, adult cases have been excluded from the current review.

221 Two major genetic variants have recurrently been described in CMN; t(12;15)(q13;q25), 222 resulting in a fusion of ETV6 and NTRK3, and trisomy 11 [13,18,19,40]. These genetic 223 aberrations were only identified in cellular and (less common) mixed type CMN. Of interest, the 224 other recurrently but rarely reported genetic aberrations (i.e. trisomy 2/8/9/10/17/18/20) also only 225 occurred in mixed and cellular type CMN [30,65-72]. This clonality may be illustrative for more 226 malignant disease as these are the subtypes that seem to behave more aggressively. However, no 227 biological studies have been performed to functionally verify this, as yet. We assume that all 228 aforementioned genetic aberrations are somatic, since no germline genetic aberrations associated 229 with CMN have been described. This is in line with the observation that bilateral CMN has never 230 been reported. Besides the diagnosis of Beckwith-Wiedemann syndrome in $3 \mathrm{CMN}$ patients, no 231 association with genetic predisposition syndromes has been reported up until now $[5,18,36]$. 232 Occurrence of CMN in two siblings has been reported once [73]. 
233 Overall survival of CMN patients was excellent (5-year overall survival $\pm 95 \%$ ). Nevertheless, it 234 was not $100 \%$ as suggested in earlier reports [16,42]. It is remarkable that causes of death were 235 treatment-related in about half of the cases and most of these patients were very young (median 236 age at diagnosis: 0 days, newborn) [2,10,13,15,17,18,35,38,39]. This underscores that these 237 infants with renal tumors deserve special attention with respect to timing and type of treatment, 238 and need a dedicated expert pediatric oncology setting. Relapses were described in only $4 \%$ of 239 the patients $[2,13,15,18,19,35]$. Virtually all relapses occurred within 12 months after diagnosis, 240 indicating that close monitoring of all cases should be advised for at least 1 year following end of 241 treatment. Most relapses occurred locally, however also metastatic relapses have been reported 242 (Supplemental Table S5). About 69\% of the relapsed patients survived after relapse treatment 243 consisting of individualized combinations of surgery, chemotherapy and radiotherapy 244 (Supplemental Table S5) [2,13,15,18,19,35].

245 Factors that seem to negatively influence outcome of CMN patients were stage III disease and 246 cellular subtype (Supplemental Table S4, S5 and S6) [15]. In addition to these factors, 247 Furtwangler et al. described age $\geq 3$ months to be associated with the occurrence of relapse based 248 on a univariate analysis of $50 \mathrm{CMN}$ cases, which can probably be attributed to the observation 249 that the more aggressive cellular subtype occurs most often in older patients [15]. According to 250 the current review, patients with relapse indeed seemed to be slightly older (median age 251 approximately 3.8 months) compared to patients without relapse (median age <1 month) 252 (Supplemental Table S5). In contrast, most deceased CMN patients were relatively young 253 (median age 0 days, newborn), mainly due to the high incidence of treatment-related mortality 254 among these very young patients (Supplemental Table S4). It is currently not possible to 255 elucidate the prognostic value of $\mathrm{t}(12 ; 15)(\mathrm{p} 13 ; \mathrm{q} 25)$ and trisomy 11 in $\mathrm{CMN}$ patients due to lack 256 of published data $[13,18,19]$.

257 Designing a standard of care for CMN patients is a challenge based on the limited available 258 evidence. It is obvious that patients with stage I/II disease, representing over $80 \%$ of the CMN 259 patients, benefit from a surgery only strategy [15,16,74]. Particularly in CMN cases, removing 260 perirenal fat during surgery is considered the golden standard, as CMN tumors often show 261 infiltrative growth into the perirenal fat [1]. Throughout the world immediate surgery is 262 recommended for renal tumors in patients under 6 months of age due to the higher probability of 263 pathology other than Wilms' tumor in this age group [4,75]. However, consideration of pre- 
264 operative chemotherapy (AV) may be justified in a small subset of these young patients, when 265 imaging or clinical symptoms suggest a high risk of operative or anesthetic complications or inoperability, even by an experienced surgical team. Partial nephrectomy or nephron-sparing surgery has only been performed in a small subset of patients and in 3 of 6 such cases, reexcision was necessary [15]. It is important that, especially in the neonatal setting, the risk of surgery should be weighed carefully against the risk of pre-operative chemotherapy. Stage III CMN patients represent a challenging subgroup with respect to the development of proper guidelines. For most of the cases surgery only seems to be sufficient, especially for stage

272 III cases of the classic or mixed histological subtype. Of 12 well-documented classic and mixed 273 type stage III patients treated without additional chemotherapy, one patient $(8 \%)$ suffered from a 274 relapse, but survived after relapse treatment (Supplemental Table S6). In contrast, 7/12 (58\%) 275 stage III cases of the cellular type treated with surgery only suffered from a relapse, while 4/14 $276(29 \%)$ stage III cellular type cases treated with adjuvant chemotherapy developed a relapse. 277 Hence, evidence that additional chemotherapy is reasonable for stage III cellular type cases is not 278 available due to a small dataset including selected subjects (Supplemental Table S6) [15,16,18]. 279 Chemosensitivity is documented in CMN patients; treatment of patients with pre-operative 280 actinomycin/vincristine resulted in a reduction in tumor size or necrotizing of the tumor in all 281 reported patients $[15,16]$. In addition, Loeb et al described three patients with recurrent cellular $282 \mathrm{CMN}$ who showed a complete response to different combinations of chemotherapy 283 (Supplemental Table S5) [76]. However, based on the results of this review, caution with respect 284 to chemotherapy-related toxicity is important in these young children (Supplemental Table S4). 285 Targeted therapy might be an option for cases with progressive disease that do not respond to 286 chemotherapy. In particular Crizotinib, an ALK inhibitor which proved to be of benefit for acute 287 lymphoblastic leukemia patients harboring the ETV6-NTRK3 transcript, resulting from the same $288 \mathrm{t}(12 ; 15)(\mathrm{p} 13 ; \mathrm{q} 25)$ as described in CMN cases, could be considered as a potential compound in 289 highly selected aggressive cases [77]. The role of radiotherapy for CMN patients is uncertain, 290 and considering the fact that late effects of radiotherapy are suspected to be substantial in this 291 relatively young group of patients, radiotherapy should be reserved for highly selected, 292 aggressive and chemotherapy resistant cases only.

293 Because of the small number of relapsed CMN patients and the different treatment regimens 294 applied in these patients, designing evidence-based treatment guidelines for relapsed CMN is not 
295 possible. Treatment of such patients requires an individualized approach in dedicated centers for 296 pediatric oncology.

297 Based on this overview, we conclude that CMN is a disease that presents at young age, most 298 commonly in the first months of life. Most CMN patients present with stage I/II disease, for 299 which surgery only is the recommended treatment. Based on the very limited available data, 300 partial nephrectomy or nephron-sparing surgery is currently not recommended for CMN patients. 301 There is insufficient evidence for recommending adjuvant chemotherapy in patients with stage 302 III disease, due to the small number of reported cases and lack of clinical trials. Histologically 303 confirmed stage IV or stage V CMN cases have not been described. Although initial surgery is 304 recommended for renal tumors in patients under 6 months of age, consideration of pre-operative 305 chemotherapy may be justified in a small subset of young patients, when imaging or clinical 306 symptoms suggest a high risk of operative of anesthetic complications. Survival rates of reported 307 CMN patients were excellent (approximately 95\% overall survival). Factors that seemed to be 308 associated with occurrence of relapse were stage III disease and cellular histology. The 309 prognostic value of $\mathrm{t}(12 ; 15)(\mathrm{p} 13 ; \mathrm{q} 25)$ and trisomy 11 , only described in cellular and mixed type $310 \mathrm{CMN}$, is hard to elucidate based on the small number of series with available data. Despite the 311 excellent outcome of patients diagnosed with CMN, the risk of treatment-related complications 312 (both surgery and chemotherapy related complications) seems to be relatively high, especially 313 when the tumor appears in the first weeks of life. This indicates that these very young patients 314 deserve special attention with respect to the timing and type of treatment, that they need a 315 dedicated expert pediatric oncology setting, and that close monitoring of toxicity is needed. It is recommended to discuss rare challenging individual CMN cases (such as (cellular) stage III and 317 relapsed cases) with steering committees of pediatric renal tumor boards, such as SIOP 318 (International Society of Pediatric Oncology) and COG (Children's Oncology Group). The 319 results of this review have guided the design of new CMN treatment recommendations, which 320 will be included in the international SIOP RTSG 2016 UMBRELLA protocol, however they 321 illustrate that longitudinal prospective registries that include histology as well as molecular 322 diagnostics are necessary for further evidence-based treatment and guideline development for 323 patients with CMN. 


\section{Conflict of interest statement}

327 The authors declare no conflict of interest.

\section{Acknowledgements}

330 The authors thank U.Vujinovic for her assistance in performing this review. This work was 331 supported by the Pediatric Oncology Center Society for Research (KOCR), Rotterdam, The 332 Netherlands, and the DaDa foundation, Nieuwerkerk aan den IIssel, The Netherlands. K.P.J.'s 333 contribution is supported by Cancer Research UK (C1188/A4614), Great Ormond Street 334 Hospital Children's Charity, EU-FP7 project European Network for Cancer research in Children 335 and Adolescents (ENCCA, grant number 261474) and the NIHR GOSH UCL Biomedical 336 Research Centre. 


\section{References}

1. Pettinato G, Manivel JC, Wick MR, et al. Classical and cellular (atypical) congenital mesoblastic nephroma: A clinicopathologic, ultrastructural, immunohistochemical, and flow cytometric study. HUM PATHOL 1989:20(7):682-690.

2. Howell CG, Othersen HB, Kiviat NE. Therapy and outcome in 51 children with mesoblastic nephroma: A report of the National Wilms' Tumor Study. J PEDIATR SURG 1982:17(6):826-831.

3. Bolande RP, Brough AJ, Izant Jr RJ. Congenital mesoblastic nephroma of infancy. A report of eight cases and the relationship to Wilms' tumor. Pediatrics 1967:40(2):272-278.

4. Van Den Heuvel-Eibrink MM, Grundy P, Graf N, et al. Characteristics and survival of 750 children diagnosed with a renal tumor in the first seven months of life: A collaborative study by the SIOP/GPOH/SFOP, NWTSG, and UKCCSG Wilms tumor study groups. Pediatr Blood Cancer 2008:50(6):1130-1134.

5. Glick RD, Hicks MJ, Nuchtern JG, et al. Renal tumors in infants less than 6 months of age. J Pediatr Surg 2004:39(4):522-525.

6. Wigger HJ. Fetal hamartoma of kidney. A benign, symptomatic, congenital tumor, not a form of Wilms' tumor. AM J CLIN PATHOL 1969:51(3):323-337.

7. Walker D, Richard GA. Fetal hamartoma of the kidney: recurrence and death of patient. J UROL 1973:110(3):352-353.

8. Fraser GC. Renal neoplasm in the newborn infant. BR J UROL 1967:39(4):509-511.

9. Favara BE, Johnson W, Ito J. Renal tumors in the neonatal period. CANCER 1968:22(4):845-855.

10. Sandstedt B, Delemarre JFM, Krul EJ, et al. Mesoblastic nephromas: A study of 29 tumours from the SIOP nephroblastoma file. HISTOPATHOLOGY 1985:9(7):741-750.

11. Marsden HB, Newton Jr WA. New look at mesoblastic nephroma. J CLIN PATHOL 1986:39(5):508-513.

12. Beckwith JB, Weeks DA. Congenital mesoblastic nephroma: When should we worry? ARCH PATHOL LAB MED 1986:110(2):98-99.

13. Watanabe N, Haruta M, Soejima H, et al. Duplication of the paternal IGF2 allele in trisomy 11 and elevated expression levels of IGF2 mRNA in congenital mesoblastic nephroma of the cellular or mixed type. Genes Chromosomes Cancer 2007:46(10):929935.

14. Knezevich SR, Garnett MJ, Pysher TJ, et al. ETV6-NTRK3 gene fusions and trisomy 11 establish a histogenetic link between mesoblastic nephroma and congenital fibrosarcoma. Cancer Res 1998:58(22):5046-5048.

15. Furtwaengler R, Reinhard H, Leuschner I, et al. Mesoblastic nephroma--a report from the Gesellschaft fur Padiatrische Onkologie und Hamatologie (GPOH). CANCER 2006:106(10):2275-2283.

16. England RJ, Haider N, Vujanic GM, et al. Mesoblastic nephroma: A report of the United Kingdom children's cancer and leukaemia group (CCLG). Pediatr Blood Cancer 2011:56(5):744-748.

17. Leclair MD, El-Ghoneimi A, Audry G, et al. The outcome of prenatally diagnosed renal tumors. J Urol 2005:173(1):186-189.

18. Bayindir P, Guillerman RP, Hicks MJ, et al. Cellular mesoblastic nephroma (infantile renal fibrosarcoma): Institutional review of the clinical, diagnostic imaging, and 
pathologic features of a distinctive neoplasm of infancy. Pediatr Radiol 2009:39(10):1066-1074.

19. Chaudry G, Perez-Atayde AR, Ngan BY, et al. Imaging of congenital mesoblastic nephroma with pathological correlation. Pediatr Radiol 2009:39(10):1080-1086.

20. Bauer JH, Durham J, Miles J. Congenital mesoblastic nephroma presenting with primary reninism. J PEDIATR 1979:95(2):268-272.

21. Daskas N, Argyropoulou M, Pavlou M, et al. Congenital mesoblastic nephroma associated with polyhydramnios and hypercalcemia. Pediatr Nephrol 2002:17(3):187189.

22. Ferraro EM, Klein SA, Fakhry J, et al. Hypercalcemia in Association with Mesoblastic Nephroma - Report of a Case and Review of the Literature. Pediatric Radiology 1986:16(6):516-517.

23. Fung TY, Hedy Fung YM, Ng PC, et al. Polyhydramnios and hypercalcemia associated with congenital mesoblastic nephroma: Case report and a new appraisal. OBSTET GYNECOL 1995:85(5 II SUPPL.):815-817.

24. Jayabose S, Iqbal K, Newman L, et al. Hypercalcemia in childhood renal tumors. CANCER 1988:61(4):788-791.

25. Kelner M, Droulle P, Didier F, et al. The vascular "ring" sign in mesoblastic nephroma: Report of two cases. Pediatr Radiol 2003:33(2):123-128.

26. Khashu M, Osiovich H, Sargent MA. Congenital mesoblastic nephroma presenting with neonatal hypertension. J Perinatol 2005:25(6):433-435.

27. Rousseau-Merck MF, Nogues C, Roth A. Hypercalcemic infantile renal tumors: Morphological, clinical, and biological heterogeneity. PEDIATR PATHOL 1985:3(24):155-164.

28. Shanbhogue LKR, Gray E, Miller SS. Congenital mesoblastic nephroma of infancy associated with hypercalcemia. J UROL 1986:135(4):771-772.

29. Soheilipour F, Amineh MA, Hashemipour M, et al. Pamidronate therapy for hypercalcemia and congenital mesoblastic nephroma: A case report. Cases J 2009:2(12).

30. Srivastava T, Kats A, Martin TJ, et al. Parathyroid-hormone-related protein-mediated hypercalcemia in benign congenital mesoblastic nephroma. Pediatr Nephrol 2011:26(5):799-803.

31. Takahashi H, Matsubara S, Kuwata T, et al. Maternal manifestation of Ballantyne's syndrome occurring concomitantly with the development of fetal congenital mesoblastic nephroma. J Obstet Gynaecol Res 2014.

32. Vido L, Carli M, Rizzononi G. Congenital mesoblastic nephroma with hypercalcemia. Pathogenetic role of prostaglandins. AM J PEDIATR HEMATOL ONCOL 1986:8(2):149-152.

33. Woolfield NF, Abbott GD, McRae CU. A mesoblastic nephroma with hypercalcaemia. AUST PAEDIATR J 1988:24(5):309-310.

34. Yokomori K, Hori $\mathrm{T}$, Takemura $\mathrm{T}$, et al. Demonstration of both primary and secondary reninism in renal tumors in children. J PEDIATR SURG 1988:23(5):403-409.

35. Barrantes JC, Toyn C, Muir KR, et al. Congenital mesoblastic nephroma: Possible prognostic and management value of assessing DNA content. J CLIN PATHOL 1991:44(4):317-320.

36. Sutherland RW, Wiener JS, Hicks MJ, et al. Congenital mesoblastic nephroma in a child with the Beckwith-Wiedemann syndrome. J UROL 1997:158(4):1532-1533. 
429 37. Argani P, Ladanyi M. Recent advances in pediatric renal neoplasia. Adv Anat Pathol 2003:10(5):243-260.

38. Cook HT, Taylor GM, Malone P, et al. Renin in mesoblastic nephroma: An immunohistochemical study. HUM PATHOL 1988:19(11):1347-1351.

39. Malone PS, Duffy PG, Ransley PG, et al. Congenital mesoblastic nephroma, renin production, and hypertension. J PEDIATR SURG 1989:24(6):599-600.

40. Anderson J, Gibson S, Sebire NJ. Expression of ETV6-NTRK in classical, cellular and mixed subtypes of congenital mesoblastic nephroma. Histopathology 2006:48(6):748753.

41. Wang ZP, Li K, Dong KR, et al. Congenital mesoblastic nephroma: Clinical analysis of eight cases and a review of the literature. Oncol Lett 2014:8(5):2007-2011.

42. Saula PW, Hadley GP. Pediatric non-Wilms' renal tumors: a Third World experience. World J Surg 2012:36(3):565-572.

43. Bitter JJ, Harrison DA, Kaplan J, et al. Mesoblastic nephroma. J COMPUT ASSISTED TOMOGR 1982:6(1):180-183.

44. Chen C, Zhu YH, Ni CJ, et al. Development of pulmonary metastasis after removal of the primary tumor: A case report of an adult mesoblastic nephroma and review of the literature. Int Cancer Conf J 2012:1(4):190-194.

45. Daniel L, Lechevallier E, Bouvier C, et al. Adult mesoblastic nephroma. Pathol Res Pract 2000:196(2):135-139.

46. Ding Y, He D, Zhou J, et al. Multiphasic contrast-enhanced CT and MRI findings of adult mesoblastic nephroma: A report of two cases. Indian J Radiol Imaging 2013:23(1):78-80.

47. Durham JR, Bostwick DG, Farrow GM, et al. Mesoblastic nephroma of adulthood: Report of three cases. AM J SURG PATHOL 1993:17(10):1029-1038.

48. Freeby JA, Fishman EK, Marshall FF, et al. Mesoblastic nephroma in an adult: Spiral CT appearance. ABDOM IMAGING 1997:22(4):439-440.

49. Groves AM, Hegarty PK, Moxon R, et al. Adult mesoblastic nephroma: Appearances on magnetic resonance imaging. Magn Reson Imaging 2004:22(7):1043-1045.

50. Levin NP, Damjanov I, Depillis VJ. Mesoblastic nephroma in an adult patient. Recurrence 21 year after removal of the primary lesion. CANCER 1982:49(3):573-577.

51. Magro G, Cavallaro V, Torrisi A, et al. Intrarenal solitary fibrous tumor of the kidney. Report of a case with emphasis on the differential diagnosis in the wide spectrum of monomorphous spindle cell tumors of the kidney. Pathol Res Pract 2002:198(1):37-43.

52. Malberger E. Aspiration cytology of mesoblastic nephroma in an adult: Diagnostic dilemma. Diagn Cytopathol 2000:23(2):124-126.

53. Moon JW, Kim KD, Shin DH, et al. Pulmonary metastatic recurrence of mesoblastic nephroma in adulthood. Respir Med Extra 2005:1(3):57-59.

54. Moslemi MK. Adult mesoblastic nephroma: a case with fatal recurrence. Urol J 2008:5(2):136-137.

55. Roy PG, Roy D, Agarwal SB, et al. Mesoblastic nephroma in an adult: A case report [2]. Ir J Med Sci 2002:171(4):236-237.

56. Shiraishi K, Yamamoto M, Gondo T, et al. Mesoblastic nephroma in adulthood: A case report. Int J Urol 1999:6(8):414-418.

57. Trillo AA. Adult variant of congenital mesoblastic nephroma. ARCH PATHOL LAB MED 1990:114(5):533-535. 
475

476

477

478

479

480

481

482

483

484

485

486

487

488

489

490

491

492

493

494

495

496

497

498

499

500

501

502

503

504

505

506

507

508

509

510

511

512

513

514

515

516

517

518

519

520
58. Truong LD, Williams R, Ngo T, et al. Adult mesoblastic nephroma. Expansion of the morphologic spectrum and review of literature. Am J Surg Pathol 1998:22(7):827-839.

59. Tulbah A, Akhtar M. Mesoblastic nephroma in an adult: HUMANA PRESS; 1997.

60. Van Velden DJJ, Schneider JW, Allen FJ. A case of adult mesoblastic nephroma: Ultrastructure and discussion of histogenesis. J UROL 1990:143(6):1216-1219.

61. Wang J, Weiss LM, Hu B, et al. Usefulness of immunohistochemistry in delineating renal spindle cell tumours. A retrospective study of 31 cases. Histopathology 2004:44(5):462471.

62. Yanai H, Ikeda A, Kadena H, et al. Adult mesoblastic nephroma with ciliated epithelium. A case report. Pathol Res Pract 2000:196(4):265-268.

63. Moslemi MK. Mixed epithelial and stromal tumor of the kidney or adult mesoblastic nephroma: An update. Urol J 2010:7(3):141-147.

64. Michal M, Syrucek M. Benign mixed epithelial and stromal tumor of the kidney. Pathol Res Pract 1998:194(6):445-448.

65. Becroft DMO, Mauger DC, Skeen JE, et al. Good prognosis of cellular mesoblastic nephroma with hyperdiploidy and relaxation of imprinting of the maternal IGF2 gene. PEDIATR PATHOL LAB MED 1995:15(5):679-688.

66. Bernstein R, Zeltzer PM, Lin F, et al. Trisomy 11 and other nonrandom trisomies in congenital fibrosarcoma. CANCER GENET CYTOGENET 1994:78(1):82-86.

67. Dal Cin P, Lipcsei G, Hermand G, et al. Congenital mesoblastic nephroma and trisomy 11. Cancer Genet Cytogenet 1998:103(1):68-70.

68. Kovacs G, Szucs S, Maschek H. Two chromosomally different cell populations in a partly cellular congenital mesoblastic nephroma. ARCH PATHOL LAB MED 1987:111(4):383-385.

69. Lowery $\mathrm{M}$, Issa $\mathrm{B}$, Pysher $\mathrm{T}$, et al. Cytogenetic findings in a case of congenital mesoblastic nephroma. CANCER GENET CYTOGENET 1995:84(2):113-115.

70. Roberts P, Lockwood LR, Lewis IJ, et al. Cytogenetic abnormalities in mesoblastic nephroma: A link to Wilms' tumour? MED PEDIATR ONCOL 1993:21(6):416-420.

71. Rubin BP, Chen CJ, Morgan TW, et al. Congenital mesoblastic nephroma $\mathrm{t}(12 ; 15)$ is associated with ETV6-NTRK3 gene fusion: Cytogenetic and molecular relationship to congenital (infantile) fibrosarcoma. Am J Pathol 1998:153(5):1451-1458.

72. Speleman F, Van Den Berg E, Dhooge C, et al. Cytogenetic and molecular analysis of cellular atypical mesoblastic nephroma. Genes Chromosomes Cancer 1998:21(3):265269.

73. Fuchs IB, Henrich W, Brauer M, et al. Prenatal diagnosis of congenital mesoblastic nephroma in 2 siblings. J Ultrasound Med 2003:22(8):823-827.

74. Beckwith JB. Letter to the editor. PEDIATR PATHOL 1993:13:3.

75. Metzger ML, Dome JS. Current therapy for Wilms' tumor. The oncologist 2005:10(10):815-826.

76. Loeb DM, Hill DA, Dome JS. Complete response of recurrent cellular congenital mesoblastic nephroma to chemotherapy. J Pediatr Hematol Oncol 2002:24(6):478-481.

77. Taipale M, Krykbaeva I, Whitesell L, et al. Chaperones as thermodynamic sensors of drug-target interactions reveal kinase inhibitor specificities in living cells. Nat Biotechnol 2013:31(7):630-637. 


\section{Legends}

522

523 Figure 1: $\quad$ Selection of articles

524 Figure 2: $\quad$ Stage according to histological subtype (reported in non-overlapping series $\geq 10$

525 cases)

526

527 Table 1: Non-overlapping series reporting $\geq 10 \mathrm{CMN}$ patients

Table 2: $\quad$ Stage, histology and outcome of reported CMN cases harboring $\mathrm{t}(12 ; 15)(\mathrm{p} 13 ; \mathrm{q} 22)$ or trisomy 11

\section{Supplemental Table 1:}

Available series reporting $\geq 10 \mathrm{CMN}$ patients

532 Supplemental Table S2:

$\mathrm{CMN}$ patients described in case reports

\section{Supplemental Table S3:}

Immunohistochemical staining of $53 \mathrm{CMN}$ patients described in

\section{Supplemental Table S4:} case reports

\section{Supplemental Table S5:} patients 
Table 1. Non-overlapping series reporting $\geq 10 \mathrm{CMN}$ patients

\begin{tabular}{|c|c|c|c|c|c|c|c|c|c|c|c|c|c|c|c|c|c|c|c|c|c|c|}
\hline \multirow{2}{*}{ Author, year } & \multirow[t]{2}{*}{$\mathbf{M} / \mathbf{F}$} & \multirow[t]{2}{*}{$\mathbf{L} / \mathbf{R}$} & \multirow{2}{*}{$\begin{array}{l}\text { Median age } \\
\text { (range) }\end{array}$} & \multicolumn{4}{|c|}{ Presenting symptoms } & \multicolumn{3}{|c|}{ Stage } & \multicolumn{4}{|c|}{ Treatment } & \multicolumn{3}{|c|}{$\begin{array}{l}\text { Histologic } \\
\text { patterns }\end{array}$} & \multicolumn{2}{|c|}{ Genetics } & \multirow[t]{2}{*}{ EFS } & \multirow[t]{2}{*}{ OS } & \multirow{2}{*}{$\begin{array}{c}\text { Median follow- } \\
\text { up (range) }\end{array}$} \\
\hline & & & & AM & HT & HE & Other & I/II & III & IV & Pr-CT & $\mathbf{S}$ & P-CT & RT & Cl & $\mathbf{M}$ & $\mathrm{Ce}$ & $t(12 ; 15)$ & Trisomy 11 & & & \\
\hline 1. Howell, 1982 & $33 / 18$ & $26 / 25$ & $2.3 \mathrm{~m}$ & 48 & 2 & 9 & 6 & 39 & 12 & 0 & - & 51 & 28 & 4 & \multicolumn{3}{|l|}{ NA } & NA & NA & $98 \%$ & $98 \%$ & $3.2 \mathrm{y}(4 \mathrm{~m}-11.5 \mathrm{y})$ \\
\hline 2. Sandstedt, 1985 & $11 / 18$ & $13 / 16$ & NA & 18 & - & 5 & 5 & 21 & 8 & 0 & - & 29 & 5 & 1 & 9 & - & 20 & NA & NA & $93 \%$ & $93 \%$ & $>4 y$ \\
\hline $\begin{array}{l}\text { 3. Cook, } 1988 \text { / } \\
\text { Malone, } 1989\end{array}$ & $9 / 3$ & $3 / 9$ & $3 d(1 d-2.5 y)$ & 11 & 4 & 1 & NA* & 11 & 1 & 0 & - & 12 & 1 & - & \multicolumn{3}{|l|}{ NA } & NA & NA & $83 \%$ & $83 \%$ & $7.3 \mathrm{y} \dagger$ \\
\hline 4. Barrantes, 1991 & $8 / 5$ & $9 / 4$ & Od (0d-19m) & NA* & - & - & - & 12 & 0 & $1^{\#}$ & - & 13 & 4 & 3 & 9 & 1 & 3 & NA & NA & $85 \%$ & $85 \%$ & $5.8 \mathrm{y}$ \\
\hline 5. Leclair, 2005 & NA & NA & NA & \multicolumn{4}{|l|}{ NA } & 25 & 1 & 0 & - & 26 & - & - & \multicolumn{2}{|l|}{21} & 5 & NA & NA & $96 \%$ & $96 \%$ & $\pm 3.5 \mathrm{y}$ \\
\hline 6. Anderson, 2006 & NA & NA & $2 \mathrm{~m}(0 \mathrm{~d}-11 \mathrm{~m})$ & \multicolumn{4}{|l|}{ NA } & 11 & 2 & 0 & - & 13 & - & - & 3 & 6 & 4 & $3 / 13$ & NA & $85 \%$ & $100 \%$ & NA \\
\hline 7. Furtwaengler, 2006 & $34 / 16$ & $21 / 29$ & $18.5 \mathrm{~d}(0 \mathrm{~d}-2.6 \mathrm{y})$ & 27 & 16 & 1 & 6 & 41 & 9 & 0 & 5 & 50 & 6 & 1 & 29 & - & 21 & NA & NA & $94 \%$ & $95 \%$ & $4.2 \mathrm{y}(0.8-8.3 \mathrm{y})$ \\
\hline 8. Watanabe, 2007 & $7 / 6$ & NA & $30 d(5 d-7 m)$ & \multicolumn{4}{|l|}{ NA } & NA & & & \multicolumn{4}{|l|}{ NA } & 4 & 1 & 8 & $8 / 12$ & $7 / 13$ & $92 \%$ & $92 \%$ & NA \\
\hline 9. Bayindir, 2009 & $7 / 3$ & $5 / 5$ & $3.1 \mathrm{~m}(6 \mathrm{~d}-5.5 \mathrm{~m})$ & 9 & 7 & 2 & 4 & 7 & 3 & 0 & 2 & 9 & 2 & - & 2 & 2 & 6 & $2 / 10$ & NA & $70 \%$ & $90 \%$ & $3.6 y(6 m-7 y) \dagger$ \\
\hline 10. Chaudry, 2009 & $15 / 15$ & $14 / 16$ & NA & NA* & - & - & - & \multicolumn{3}{|l|}{ NA } & NA & 30 & NA & NA & 12 & 3 & 15 & $6 / 30$ & NA & $93 \%$ & NA & NA \\
\hline 11. England, 2011 & $28 / 19$ & $23 / 24$ & $1 \mathrm{~m}(0 \mathrm{~d}-3.8 \mathrm{y})$ & NA* & NA* & - & - & 41 & 6 & 0 & 2 & 47 & 2 & - & 23 & 10 & 14 & NA & NA & $100 \%$ & $100 \%$ & $4.4 \mathrm{y}(1 \mathrm{~m}-10 \mathrm{y})$ \\
\hline 12. Saula, 2012 & $7 / 5$ & NA & NA & 12 & 2 & - & 2 & \multicolumn{3}{|l|}{ NA } & - & 12 & 2 & - & \multicolumn{3}{|l|}{ NA } & NA & NA & $92 \%$ & $100 \%$ & $5-10 y$ \\
\hline Total & $159 / 108$ & $114 / 128$ & Range 0d-2.3m & 125 & 31 & 18 & 23 & 208 & 42 & 1 & 9 & 292 & 50 & 9 & 91 & 23 & 96 & $16 / 52$ & $7 / 13$ & $94 \%$ & $95 \%$ & Range 3.5-5.8y \\
\hline \multicolumn{23}{|c|}{ 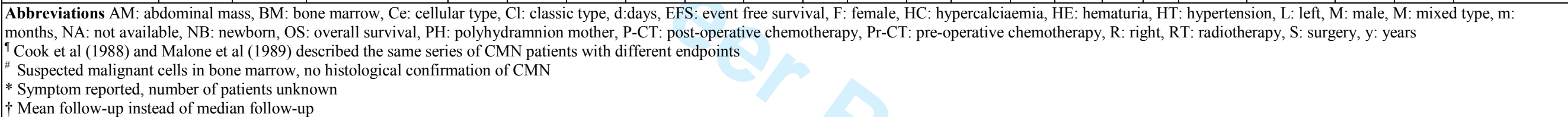 } \\
\hline
\end{tabular}


Table 2. Stage, histology and outcome of reported CMN cases harboring $\mathrm{t}(12 ; 15)(\mathrm{p} 13 ; \mathrm{q} 22)$ or trisomy 11

\begin{tabular}{|c|c|c|c|c|}
\hline & \multicolumn{2}{|c|}{$\mathbf{t}(12 ; 15)(\mathbf{p 1 3} ; \mathbf{q} 22) *$} & \multicolumn{2}{|c|}{ Trisomy $11 *$} \\
\hline & Series $\geq 10$ patients & Case reports $* *$ & Series $\geq 10$ patients & Case reports $* *$ \\
\hline $\begin{array}{l}\text { Number of cases } \\
\text { analyzed }\end{array}$ & 65 & NA & 13 & NA \\
\hline Number of positive cases & 19 & 16 & 7 & 15 \\
\hline Stage & $\begin{array}{l}\text { I/II: } 3 \\
\text { III: } 1 \\
\text { Unknown: } 15\end{array}$ & $\begin{array}{l}\text { I/II: } 5 \\
\text { III: } 4 \\
\text { Unknown: } 7\end{array}$ & $\begin{array}{l}\text { I/II: } 0 \\
\text { III: } 0 \\
\text { Unknown: } 7\end{array}$ & $\begin{array}{l}\text { I/II: } 7 \\
\text { III: } 2 \\
\text { Unknown: } 6\end{array}$ \\
\hline Histology & $\begin{array}{l}\text { Classic: } 0 \\
\text { Mixed: } 0 \\
\text { Cellular: } 19 \\
\text { Unknown: } 0\end{array}$ & $\begin{array}{l}\text { Classic: } 0 \\
\text { Mixed: } 4 \\
\text { Cellular: } 10 \\
\text { Unknown: } 2\end{array}$ & $\begin{array}{l}\text { Classic: } 0 \\
\text { Mixed: } 0 \\
\text { Cellular: } 7 \\
\text { Unknown: } 0\end{array}$ & $\begin{array}{l}\text { Classic: } 0 \\
\text { Mixed: } 3 \\
\text { Cellular: } 9 \\
\text { Unknown: } 3\end{array}$ \\
\hline Outcome data available & $\mathrm{n}=13$ & $\mathrm{n}=5$ & $\mathrm{n}=7$ & $\mathrm{n}=4$ \\
\hline Outcome & $\begin{array}{l}\text { Relapse: } 2 / 13 \\
\text { Dead of disease: } 1 / 13\end{array}$ & $\begin{array}{l}\text { Relapse: } 2 / 5 \\
\text { Dead of disease: } 0 / 5\end{array}$ & $\begin{array}{l}\text { Relapse: } 0 / 7 \\
\text { Dead of disease: } 0 / 7\end{array}$ & $\begin{array}{l}\text { Relapse: } 0 / 4 \\
\text { Dead of disease: } 0 / 4\end{array}$ \\
\hline
\end{tabular}

* Six cases described in series $\geq 10$ patients and 11 cases described in case reports harbored both $\mathrm{t}(12 ; 15)(\mathrm{p} 13 ; \mathrm{q} 22)$ and trisomy 11

** Case reports also included in series $\geq 10$ patients were removed from this table 


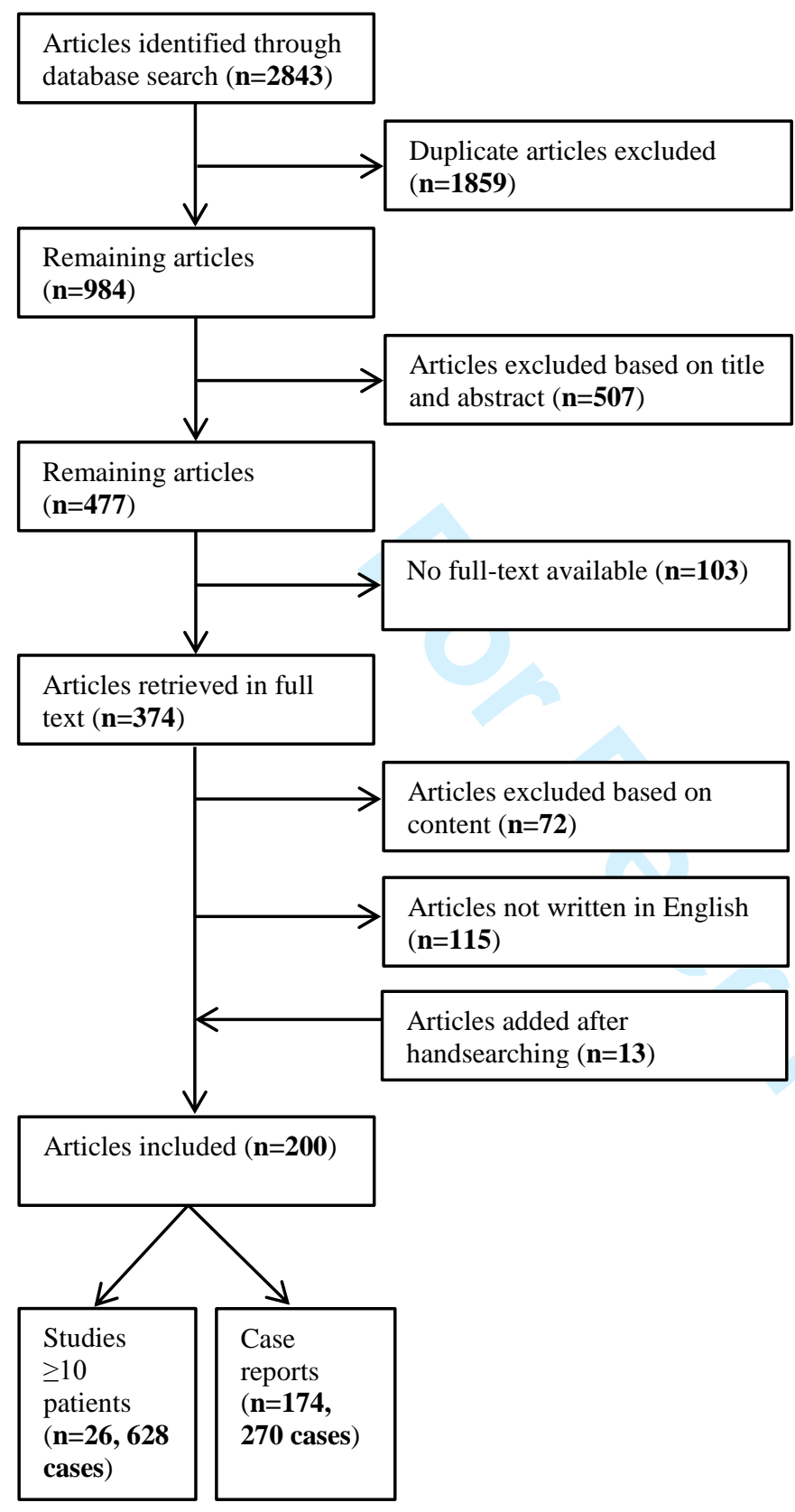




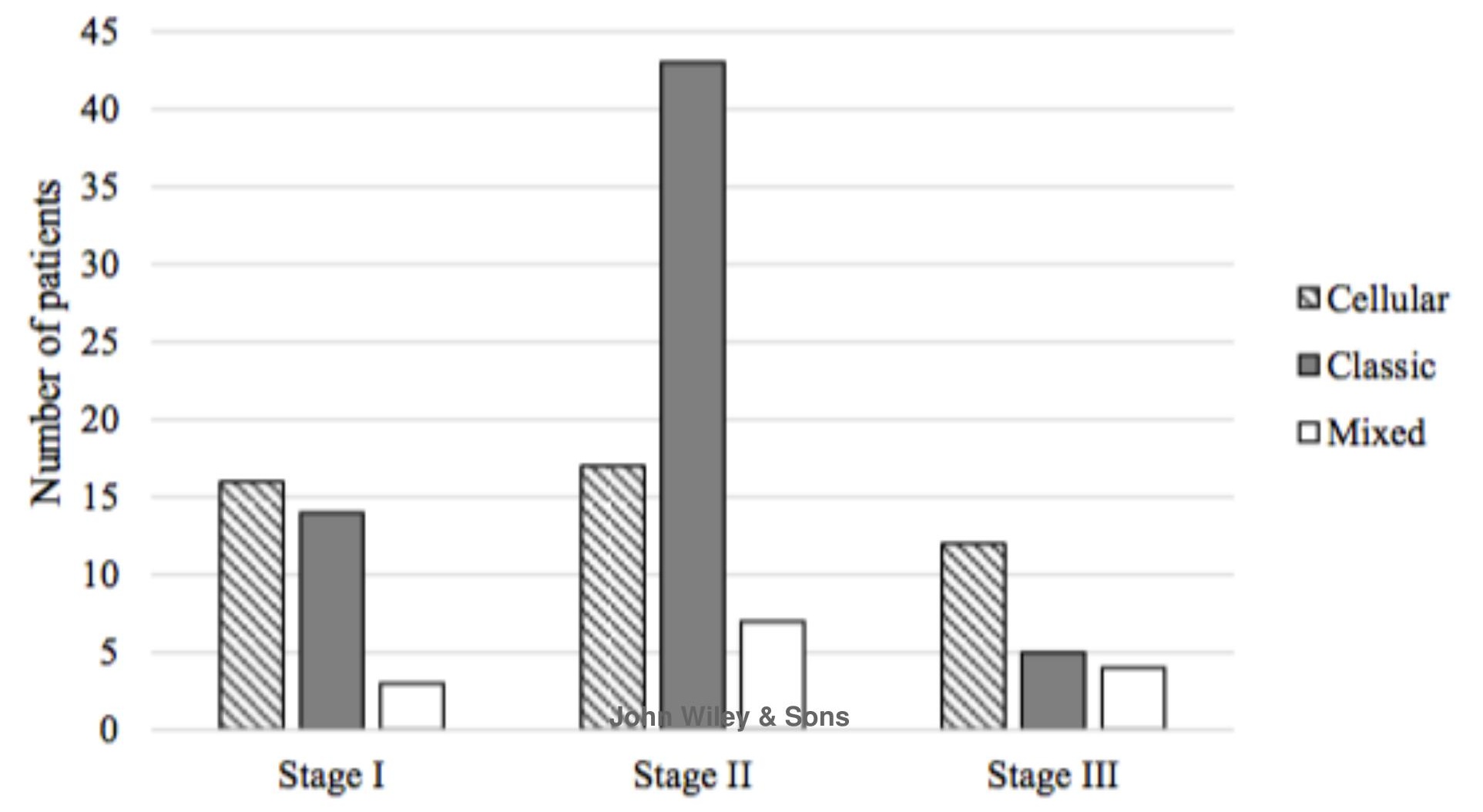


Supplemental Table S1. Available series reporting $\geq 10 \mathrm{CMN}$ patients

\begin{tabular}{|c|c|c|c|c|c|c|c|c|c|c|c|c|c|c|c|c|c|c|c|c|c|c|}
\hline \multirow{2}{*}{ Author, year } & \multirow{2}{*}{$\mathbf{M} / \mathbf{F}$} & \multirow{2}{*}{$\mathbf{L} / \mathbf{R}$} & \multirow{2}{*}{$\begin{array}{c}\text { Median age } \\
\text { (range) }\end{array}$} & \multicolumn{4}{|c|}{ Presenting symptoms } & \multicolumn{3}{|c|}{ Stage } & \multicolumn{4}{|c|}{ Treatment } & \multicolumn{3}{|c|}{$\begin{array}{c}\begin{array}{c}\text { Histologic } \\
\text { patterns }\end{array} \\
\text {. }\end{array}$} & \multicolumn{2}{|c|}{ Genetics } & \multirow{2}{*}{ EFS } & \multirow{2}{*}{ os } & \multirow{2}{*}{\begin{tabular}{|l} 
Median follow \\
up (range)
\end{tabular}} \\
\hline & & & & $\mathbf{A M}$ & HT & HE & Other & I/III & III & IV & Pr-CT & & P-CT & RT & $\mathbf{C l}$ & $\mathbf{M}$ & $\mathrm{Ce}$ & $t(12 ; 15)$ & \begin{tabular}{|l|} 
Trisomy 11 \\
\end{tabular} & & & \\
\hline \multicolumn{23}{|c|}{\begin{tabular}{|l} 
\\
NON-OVERLAPPING SERIES
\end{tabular}} \\
\hline 1. Howell, 1982 & $33 / 18$ & $26 / 25$ & $2.3 \mathrm{~m}$ & 48 & 2 & 9 & 6 & 39 & 12 & 0 & - & 51 & 28 & 4 & \multicolumn{3}{|l|}{ NA } & NA & NA & $98 \%$ & $98 \%$ & $3.2 \mathrm{y}(4 \mathrm{~m}-11.5 \mathrm{y}$ \\
\hline 2. Sandstedt, 1985 & $11 / 18$ & $13 / 16$ & NA & 18 & - & 5 & 5 & 21 & 8 & 0 & - & 29 & 5 & 1 & 9 & T- & 20 & NA & NA & $93 \%$ & $93 \%$ & $>4 y$ \\
\hline $\begin{array}{l}\text { 3. Cook, } 1988 \text { ! } \\
\text { Malone, } 1989 \text { " }\end{array}$ & 9/3 & $3 / 9$ & $3 d(1 d-2.5 y)$ & 11 & 4 & 1 & $\mathrm{NA}^{*}$ & 11 & 1 & 0 & - & 12 & 1 & - & \multicolumn{3}{|l|}{ NA } & NA & NA & $83 \%$ & $83 \%$ & $7.3 \mathrm{y} \uparrow$ \\
\hline 4. Barrantes, 1991 & $8 / 5$ & $9 / 4$ & Od (0d-19m) & $\mathrm{NA}^{*}$ & - & - & - & 12 & 0 & $1^{\#}$ & - & 13 & 4 & 3 & 9 & 1 & 3 & NA & NA & $85 \%$ & $85 \%$ & $5.8 \mathrm{y}$ \\
\hline 5. Leclair, 2005 & NA & NA & NA & \multicolumn{4}{|l|}{ NA } & 25 & 1 & 0 & - & 26 & - & - & \multicolumn{2}{|l|}{21} & 5 & NA & NA & $96 \%$ & $96 \%$ & $\pm 3.5 \mathrm{y}$ \\
\hline 6. Anderson, 2006 & NA & NA & $2 \mathrm{~m}(0 \mathrm{~d}-11 \mathrm{~m})$ & \multicolumn{4}{|l|}{$\mathrm{NA}$} & 11 & 2 & 0 & - & 13 & - & - & 3 & 21 & 4 & $3 / 13$ & NA & $85 \%$ & $100 \%$ & NA \\
\hline 7. Furtwaengler, 2006 & $34 / 16$ & $21 / 29$ & $18.5 \mathrm{~d}(0 \mathrm{~d}-2.6 \mathrm{y})$ & 27 & 16 & 1 & 6 & 41 & 9 & 0 & 5 & 50 & 6 & 1 & 29 & - & 21 & NA & NA & $94 \%$ & $95 \%$ & $4.2 \mathrm{y}(0.8-8.3 \mathrm{y})$ \\
\hline 8. Watanabe, 2007 & $7 / 6$ & NA & $30 d(5 d-7 m)$ & \multicolumn{4}{|l|}{ NA } & NA & & & \multicolumn{4}{|l|}{ NA } & 4 & 1 & 8 & $8 / 12$ & $7 / 13$ & $92 \%$ & $92 \%$ & NA \\
\hline 9. Bayindir, 2009 & $7 / 3$ & $5 / 5$ & $3.1 \mathrm{~m}(6 \mathrm{~d}-5.5 \mathrm{~m})$ & 9 & 7 & 2 & 4 & 7 & 3 & 0 & 2 & 9 & 2 & - & 2 & 2 & 6 & $2 / 10$ & NA & $70 \%$ & $90 \%$ & $3.6 y(6 \mathrm{~m}-7 \mathrm{y}) \dagger$ \\
\hline \begin{tabular}{|l|} 
10. Chaudry, 2009 \\
\end{tabular} & $15 / 15$ & $14 / 16$ & NA & $\mathrm{NA}^{*}$ & - & - & - & NA & & & $\mathrm{NA}$ & 30 & $\mathrm{NA}$ & NA & 12 & 3 & 15 & $6 / 30$ & NA & $93 \%$ & NA & NA \\
\hline 11. England, 2011 & $28 / 19$ & $23 / 24$ & $1 \mathrm{~m}(0 \mathrm{~d}-3.8 \mathrm{y})$ & $\mathrm{NA}^{*}$ & $\mathrm{NA}^{*}$ & - & - & 41 & 6 & 0 & 2 & 47 & 2 & - & 23 & 10 & 14 & NA & NA & $100 \%$ & $100 \%$ & 4.4y (1m-10y) \\
\hline 12. Saula, 2012 & $7 / 5$ & $\mathrm{NA}$ & $\mathrm{NA}$ & 12 & 2 & - & 2 & $\mathrm{NA}$ & & & - & 12 & 2 & - & \multicolumn{3}{|l|}{ NA } & NA & NA & $92 \%$ & $100 \%$ & $5-10 y$ \\
\hline Total & $159 / 108$ & $114 / 128$ & Range 0d-2.3m & 125 & 31 & 18 & 23 & 208 & 42 & 1 & 9 & 292 & 50 & 9 & 91 & 23 & 96 & $16 / 52$ & $7 / 13$ & $94 \%$ & $95 \%$ & Range 3.5-5.8y \\
\hline PARTIALLY OVER & LAPPINC & SERIES & & & & & & & & & & & & & & & & & & & & \\
\hline Bogdan, 1973 & $14 / 5$ & NA & $4 \mathrm{w}(0 \mathrm{~d}-2.5 \mathrm{y})$ & 15 & - & - & 4 & NA & & & 2 & 15 & 5 & 8 & NA & & & NA & NA & $68 \%$ & $68 \%$ & $1.8 \mathrm{y}(0 \mathrm{~m}-34 \mathrm{y})$ \\
\hline Shen, $1980^{\wedge 1}$ & $5 / 5$ & $7 / 3$ & $5 d(1 d-8 m)$ & 10 & 1 & 2 & 1 & NA & & & - & 10 & 4 & - & 5 & 3 & 2 & NA & NA & $90 \%$ & $90 \%$ & $4.5 y(3.3-10 y)$ \\
\hline \begin{tabular}{|l|l} 
Snyder $1980^{\wedge^{1}}$ \\
\end{tabular} & $8 / 3$ & NA & $0 \mathrm{~d}(0 \mathrm{~d}-6 \mathrm{~m})$ & $\mathrm{NA}^{*}$ & & & 3 & 11 & 0 & 0 & - & 11 & - & 5 & 9 & - & 2 & NA & NA & $73 \%$ & $73 \%$ & NA (3-26y) \\
\hline Hartman, $1981^{\wedge 1}$ & $9 / 11$ & NA & $2 \mathrm{w}(0 \mathrm{~d}-16 \mathrm{y})$ & NA & & & & NA & & & $\mathrm{NA}$ & & & & NA & & & NA & NA & NA & NA & NA \\
\hline Chan, $1987^{\wedge}$ & $9 / 8$ & NA & \begin{tabular}{|l|} 
Cl:5.3d $(1-21 \mathrm{~d})$ \\
Ce:5.3m $(1-18 \mathrm{~m})$
\end{tabular} & $\mathrm{NA}^{*}$ & 14 & 3 & 6 & 17 & 0 & 0 & - & 17 & 3 & 2 & 9 & 8 & & NA & NA & $100 \%$ & $100 \%$ & $10 \mathrm{y} \dagger$ \\
\hline Pettinato, $1989^{\wedge 1}$ & 7/9 & $9 / 4$ & \begin{tabular}{|l|} 
Cl: $16 \mathrm{~d}$ \\
M:2.3m \\
Ce: $5.3 \mathrm{~m}$ \\
\end{tabular} & $\mathrm{NA}^{*}$ & 2 & 2 & 3 & 15 & 1 & 0 & 0 & 14 & 1 & - & 6 & 3 & 7 & NA & NA & $81 \%$ & $81 \%$ & $5.3 \mathrm{y} \dagger$ \\
\hline \begin{tabular}{|l} 
Schofield, $1993^{\wedge^{1}}$ \\
\end{tabular} & $8 / 9$ & NA & $7 d(1 d-2 y)$ & NA & & & & NA & & & 0 & 17 & 5 & - & 6 & 5 & 5 & NA & $7 / 17$ & $88 \%$ & $88 \%$ & Range $8 \mathrm{~m}-22 \mathrm{y}$ \\
\hline Mascarello, $1994^{\wedge 1,10}$ & NA & NA & NA & NA & & & & NA & & & NA & & & & 11 & 12 & & NA & $9 / 23$ & NA & NA & NA \\
\hline 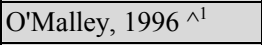 & $9 / 6$ & NA & $N A(2 d-2 y)$ & $\mathrm{NA}$ & & & & NA & & & - & 15 & 11 & T- & 1 & 6 & 9 & NA & NA & NA & NA & NA \\
\hline Knezevich, $1998^{\wedge 9,10}$ & $8 / 7$ & NA & $1 \mathrm{~m}(1 \mathrm{~d}-3 \mathrm{y})$ & NA & & & & NA & & & $\mathrm{NA}$ & & & & 4 & 2 & 9 & $10 / 15$ & $9 / 14$ & NA & NA & NA \\
\hline Shao, $2004^{\wedge 1,9,10}$ & NA & NA & NA & NA & & & & NA & & & NA & & & & 5 & - & 7 & NA & NA & NA & NA & NA \\
\hline Abosoudah, $2008^{\wedge^{10}}$ & $8 / 6$ & NA & $12 \mathrm{~d}(3 \mathrm{~d}-2 \mathrm{y})$ & $\mathrm{NA}^{*}$ & - & T- & - & $\mathrm{NA}$ & & & $\mathrm{NA}$ & & & & 4 & 1 & 9 & $9 / 10$ & NA & $86 \%$ & $93 \%$ & NA \\
\hline $\begin{array}{l}\text { Vd Heuvel-Eibrink, } \\
\left.200 \wedge^{\wedge}\right\urcorner\end{array}$ & NA & NA & $<7 \mathrm{~m}$ & NA & & & & 98 & 17 & 0 & NA & & & & NA & & & NA & NA & $94 \%$ & $96 \%$ & NA \\
\hline 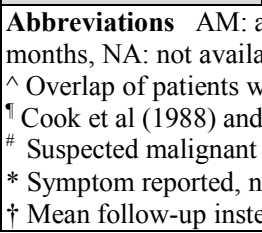 & $\begin{array}{l}\text { abdomin } \\
\text { able, NB } \\
\text { with othe } \\
\text { d Malon } \\
\text { teells in } \\
\text { number }\end{array}$ & $\begin{array}{l}\text { entres }(\mathrm{n} \\
\mathrm{tal}(198 \\
\text { ne marr }\end{array}$ & $\begin{array}{l}\text { described the sam } \\
\text { known histological c } \\
\text { known }\end{array}$ & ries of & in & th & iffe & & ts & & $1, \mathrm{~F}:$ & & & & & & & & & & & mixed \\
\hline
\end{tabular}




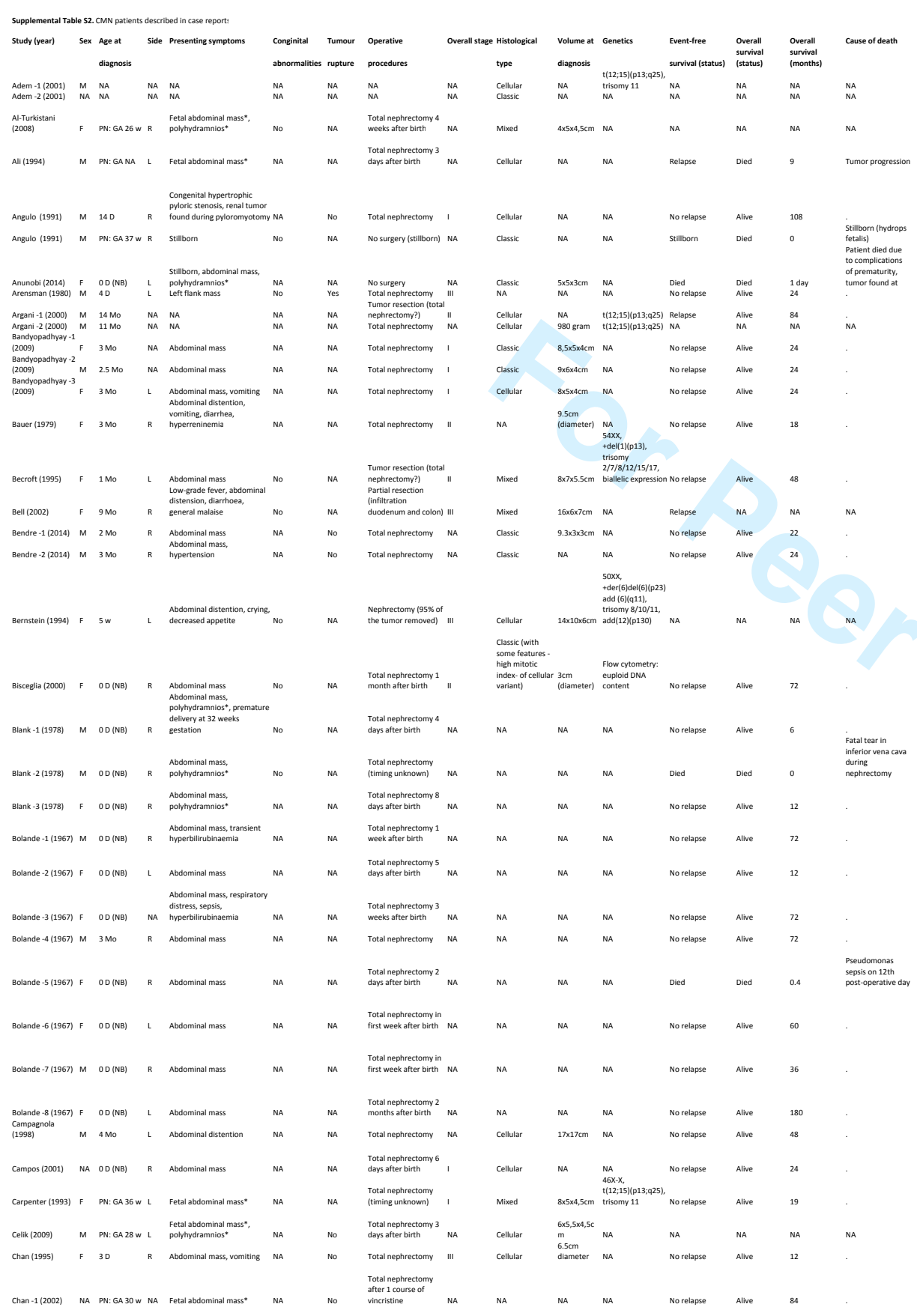


Supplemental Table S3. Immunohistochemical staining of $53 \mathrm{CMN}$ patients described in case reports

\begin{tabular}{|c|c|c|c|c|c|c|c|c|}
\hline \multirow[t]{2}{*}{ Staining } & \multicolumn{4}{|c|}{ Positive } & \multicolumn{4}{|c|}{ Negative } \\
\hline & Classic & Mixed & Cellular & NA & Classic & Mixed & Cellular & NA \\
\hline Vimentin & 7 & 5 & 17 & 3 & 1 & 2 & & \\
\hline Desmin & & & & 3 & 3 & 2 & 9 & 2 \\
\hline (Smooth muscle) actin & 3 & 3 & 5 & 3 & 2 & 1 & 5 & \\
\hline (Cyto)keratin & 1 & & 2 & & 3 & 1 & 7 & \\
\hline S-100 & & 1 & & & 2 & 1 & 3 & \\
\hline Neuronspecific enolase & & & & & 1 & & 1 & \\
\hline TrkC antibody & & & 1 & & & & & \\
\hline $\begin{array}{l}\text { Epithelial membrane } \\
\text { antigen }\end{array}$ & 3 & 3 & 3 & & 2 & & 7 & \\
\hline $\mathrm{AE} 1 / \mathrm{AE} 3$ & 2 & 2 & 2 & & 1 & 1 & 1 & \\
\hline PTHrP & & 1 & 1 & & & & & \\
\hline c-kit & 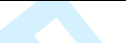 & & & 2 & 1 & & & \\
\hline Ki-67 & 1 & & 4 & & 1 & & & \\
\hline CD34 & 1 & & & & 2 & & 4 & \\
\hline Myoglobin & 4 & & & & & & 1 & \\
\hline Alpha-fetoprotein & & 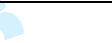 & & & & & 1 & \\
\hline Bcl-2 & 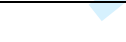 & & & & & & 1 & \\
\hline CD99 & & e & & & & & 1 & \\
\hline INI1 & & F & 4 & & & & & \\
\hline Fibronectin & 1 & 1 & 2 & & & & & \\
\hline Laminin & & & & & 1 & 1 & 2 & \\
\hline TP & & & 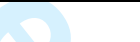 & & 2 & 3 & 2 & \\
\hline PHA & & & 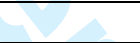 & & 3 & 2 & 2 & \\
\hline THP & 1 & & 1 & & 1 & 2 & 1 & \\
\hline $\mathrm{AH}$ & 3 & 3 & 2 & & & & & \\
\hline PSA & 1 & 1 & 1 & 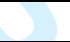 & 2 & 2 & 1 & \\
\hline WT1-GP & & & 1 & 1 & & & & \\
\hline Renin & & & & & & & & 1 \\
\hline
\end{tabular}


Supplemental Table S4. Characteristics and treatment of reported deceased CMN patients

\begin{tabular}{|c|c|c|c|c|c|c|c|}
\hline Type of report & Report & Age & Stage & $\begin{array}{l}\text { Histologic } \\
\text { subtype }\end{array}$ & Tx at diagnosis & Relapse & Cause of death \\
\hline \multirow{12}{*}{$\begin{array}{l}\text { Series } \geq 10 \\
\text { patients }\end{array}$} & Furtwangler 2006 & $6 \mathrm{~m}$ & III & Cellular & $\mathrm{PN}, \mathrm{CN}$ (rupture) & Yes & Tumor progression \\
\hline & Furtwangler 2006 & $2.7 \mathrm{y}$ & I & Cellular & $\begin{array}{l}\text { Pre-op CT, CN, } \\
\text { post-op CT }\end{array}$ & Yes & Tumor progression \\
\hline & Bayindir 2009 & $3.9 \mathrm{~m}$ & III & Cellular & Pre-op CT & No & Tumor progression \\
\hline & Watanabe 2007 & $1.1 \mathrm{y}$ & II & Cellular & $\begin{array}{l}\mathrm{CN}, \text { post-op CT } \\
\text { (NWTS-3 } \\
\text { regimen } \mathrm{K} \text { ) }\end{array}$ & Yes & Tumor progression \\
\hline & Leclair 2005 & NB & $\mathrm{I} / \mathrm{II}$ & Cellular & $\mathrm{CN}$ & No & Toxicity (surgery) \\
\hline & Barrantes 1991 & NB & II & Classic & $\mathrm{CN}, \mathrm{RT}$ & Yes & Tumor progression \\
\hline & Barrantes 1991 & NB & II & Classic & $\mathrm{CN}$ & No & Toxicity (surgery) \\
\hline & Howell 1982 & NB & III & NA & $\begin{array}{l}\text { CN (rupture), } \\
\text { AMD }\end{array}$ & No & Toxicity (chemotherapy) \\
\hline & Sandstedt 1985 & NA & NA & NA & NA & No & Toxicity (surgery) \\
\hline & Sandstedt 1985 & NA & NA & NA & NA & No & Toxicity (surgery) \\
\hline & $\begin{array}{l}\text { Cook } 1988 \\
\text { /Malone } 1989\end{array}$ & $1 d$ & III & NA & $\begin{array}{l}\text { CN (rupture), } \\
\text { post-op CT }\end{array}$ & No & Toxicity (chemotherapy) \\
\hline & $\begin{array}{l}\text { Cook } 1988 \\
\text { /Malone } 1989\end{array}$ & $3 d$ & $\mathrm{I} / \mathrm{II}$ & NA & $\mathrm{CN}$ & No & Toxicity (surgery) \\
\hline \multirow[t]{24}{*}{ Case reports } & Ali 1994 & NA & NA & Cellular & $\overline{\mathrm{CN}}$ & Yes & Tumor progression \\
\hline & Cheol 2007 & NB & NA & Cellular & None & No & Tumor progression \\
\hline & Jones 2007 & $1 \mathrm{~d}$ & III & Cellular & $\mathrm{CN}$ & Yes & Tumor progression \\
\hline & Joshi 1986 & $10 \mathrm{~m}$ & III & Cellular & $\begin{array}{l}\text { CN, post-op CT } \\
\text { (AVD), RT }\end{array}$ & Yes & Tumor progression \\
\hline & Santos 2011 & $2.8 \mathrm{y}$ & NA & Cellular & CN, post-op CT & Yes & Tumor progression \\
\hline & Vujanic 1993 & $1.2 \mathrm{y}$ & III & Cellular & $\begin{array}{l}\text { Surgery, post-op } \\
\text { CT (AV) }\end{array}$ & Yes & Toxicity (chemotherapy) \\
\hline & Angulo 1991 & NB & I & Classic & None & No & Stillborn (hydrops fetalis) \\
\hline & Chen 2003 & NB & NA & Classic & None & No & $\begin{array}{l}\text { Died directly after birth (hydrops } \\
\text { fetalis) }\end{array}$ \\
\hline & Anunobi 2014 & NB & NA & Classic & None & No & $\begin{array}{l}\text { Died } 13 \text { hours after birth } \\
\text { (prematurity, polyhydramnios } \\
\text { mother) }\end{array}$ \\
\hline & Correia 1995 & $7 \mathrm{~m}$ & I & Classic & $\mathrm{CN}$ & No & $\begin{array}{l}\text { Toxicity (peritonitis due to } \\
\text { peritoneal dialysis) }\end{array}$ \\
\hline & Favara 1968 & NB & NA & Classic & None & No & $\begin{array}{l}\text { Died } 8 \text { hours after birth (respiratory } \\
\text { distress) }\end{array}$ \\
\hline & Kumar 1985 & $0 \mathrm{~m}$ & NA & Classic & NA & NA & Toxicity (sepsis) \\
\hline & Walker 1973 & $3 \mathrm{~m}$ & NA & Classic & $\begin{array}{l}\text { CN, post-op CT } \\
\text { (ACT) }\end{array}$ & Yes & Tumor progression \\
\hline & De Paepe 2011 & NB & NA & Mixed & None & No & $\begin{array}{l}\text { Intra-uterine death (intra-tumoral } \\
\text { hemorrhage, early non-immune } \\
\text { hydrops) }\end{array}$ \\
\hline & $\begin{array}{l}\text { Heidelberger } \\
1993\end{array}$ & NB & NA & Mixed & $\mathrm{CN}$ & Yes & Tumor progression \\
\hline & Gray 1989 & NB & NA & NA & None & No & Intra-uterine death (hydrops fetalis) \\
\hline & Kotani 2010 & NB & NA & NA & $\mathrm{CN}$ & No & Toxicity (surgery) \\
\hline & Liu 1996 & NB & NA & NA & None & No & $\begin{array}{l}\text { Died directly after birth (ascites, } \\
\text { pleural effusions, pericardial } \\
\text { effusion, subcutaneous oedema) }\end{array}$ \\
\hline & Meenal 2003 & NB & NA & NA & None & No & Stillborn \\
\hline & Blank 1978 & NB & NA & NA & $\mathrm{CN}$ & No & Toxicity (surgery) \\
\hline & Bolande 1967 & NB & NA & NA & $\begin{array}{l}\text { CN, post-op CT } \\
\text { (ACT) }\end{array}$ & No & Toxicity (surgery) \\
\hline & Larson 1978 & NB & NA & NA & None & No & $\begin{array}{l}\text { Tumor progression and advanced } \\
\text { hyaline membrane disease }\end{array}$ \\
\hline & Wigger 1969 & NB & NA & NA & $\mathrm{CN}$ & No & Toxicity (surgery) \\
\hline & Wigger 1969 & NB & NA & NA & $\mathrm{CN}$ & No & Toxicity (surgery) \\
\hline
\end{tabular}

Abbreviations CN: complete nephrectomy, NA: not available, NB: newborn, PN: partial nephrectomy, post-op CT: post-operative chemotherapy, pre-op CT: pre-operative chemotherapy, Tx: treatment 
Supplemental Table S5. Characteristics, treatment and outcome of reported relapsed CMN patients

\begin{tabular}{|c|c|c|c|c|c|c|c|c|c|}
\hline Source & Report & Age & Stage & $\begin{array}{l}\text { Histologic } \\
\text { subtype }\end{array}$ & Initial treatment & $\begin{array}{l}\text { Time to } \\
\text { relapse }\end{array}$ & $\begin{array}{l}\text { Location of } \\
\text { relapse }\end{array}$ & Treatment of relapse & Outcome (follow-up time) \\
\hline \multirow{12}{*}{\begin{tabular}{|l|} 
Series $\geq 10$ \\
patients
\end{tabular}} & Furtwaengler 2006 & $3 \mathrm{~m}$ & III & Cellular & $\mathrm{CN}$ (rupture) & NA & Local & S, CT (AVD) & Alive (5.6y) \\
\hline & Furtwaengler 2006 & $6 \mathrm{~m}$ & III & Cellular & PN, CN (rupture) & NA & Local & CT (AVI) & Died of tumor progression (1y) \\
\hline & \begin{tabular}{|l|} 
Furtwaengler 2006 \\
\end{tabular} & $2.7 \mathrm{y}$ & I & Cellular & Pre-op CT, CN, post-op CT & NA & Local & CT (ICED), RT, S & Died of tumor progression $(1.5 \mathrm{y})$ \\
\hline & Bayindir 2009 & $5 \mathrm{~m}$ & III & Cellular & $\begin{array}{l}\text { Pre-op CT (AV), CN } \\
\text { (incomplete), post-op CT (AV) }\end{array}$ & $2 \mathrm{~m}$ & Local & S, CT (VCD/VP-16/IFO), RT & Alive (7y) \\
\hline & Chaudry 2009 & NA & NA & Cellular & $\mathrm{CN}$ & $<6 \mathrm{~m}$ & Local & NA & NA \\
\hline & Chaudry 2009 & NA & NA & Cellular & $\mathrm{CN}$ & $<6 \mathrm{~m}$ & Local & NA & NA \\
\hline & Watanabe 2007 & $1.1 \mathrm{y}$ & II & Cellular & $\begin{array}{l}\text { CN, post-op CT (NWTS-3 } \\
\text { regimen K) }\end{array}$ & NA & $\begin{array}{l}\text { Bone (ilium, } \\
\text { humerus, vertebrae) }\end{array}$ & NA & Died of tumor progression $(1.3 \mathrm{y})$ \\
\hline & Anderson 2006 & $\mathrm{NB}$ & III & Cellular & $\mathrm{CN}$ & $6 \mathrm{~m}$ & Local & $\mathrm{S}, \mathrm{CT}(\mathrm{VCR} / \mathrm{IFO} / \mathrm{ACT})$ & Alive (NA) \\
\hline & Barrantes 1991 & NB & II & Classic & $\mathrm{CN}, \mathrm{RT}$ & NA & NA & None & Died of tumor progression $(9 \mathrm{~m})$ \\
\hline & Bayindir 2009 & $3 \mathrm{~m}$ & II & Mixed & $\mathrm{CN}$ & $6 \mathrm{~m}$ & Lung & S, CT (VCD) & Alive $(4.5 \mathrm{y})$ \\
\hline & \begin{tabular}{|l|} 
Anderson 2006 \\
\end{tabular} & $8 \mathrm{~m}$ & III & Mixed & $\mathrm{CN}$ & $8 \mathrm{~m}$ & Local & S, CT (AVD+ICE) & Alive (NA) \\
\hline & Howell 1982 & $4 \mathrm{~m}$ & NA & NA & $\mathrm{CN}$ (spill), AV & $7 \mathrm{~m}$ & Local & $\mathrm{S}, \mathrm{CT}(\mathrm{DOX} / \mathrm{CYC})$ & Alive (1.6y) \\
\hline \multirow[t]{20}{*}{ Case reports } & Ali 1994 & $\mathrm{NB}$ & NA & Cellular & $\mathrm{CN}$ & $3 \mathrm{~m}$ & Local, brain & S, CT (type NA) & Died of tumor progression $(9 \mathrm{~m})$ \\
\hline & \begin{tabular}{|l|} 
Jones 2007 \\
\end{tabular} & NB & III & Cellular & $\mathrm{CN}$ & $6 \mathrm{~m}$ & Local & $\mathrm{S}$ & Alive $(7 \mathrm{~m})$ \\
\hline & \begin{tabular}{|l|} 
Argani 2000 \\
\end{tabular} & $1.2 \mathrm{y}$ & II & Cellular & S (type unknown) & $12 \mathrm{~m}$ & Lung & $\mathrm{S}$ & Alive $(7 y)$ \\
\hline & Glick 2004 & $3.5 \mathrm{~m}$ & II & Cellular & $\mathrm{CN}$ & $6 \mathrm{~m}$ & Lung & S, CT (type NA) & Alive $(6 \mathrm{~m})$ \\
\hline & $\begin{array}{l}\text { Gonzalez-Crussi } \\
1980\end{array}$ & $7 \mathrm{~m}$ & NA & Cellular & $\mathrm{CN}$ & $3 \mathrm{~m}$ & Lung & S, RT, CT (ACT) & Alive (5.5y) \\
\hline & Jones 2007 & $1 \mathrm{~d}$ & III & Cellular & $\mathrm{CN}$ (rupture) & $6 \mathrm{~m}$ & Local & S, CT (AVD/CYC/CIS) & Died of tumor progression (1.6y) \\
\hline & Joshi 1986 & $10 \mathrm{~m}$ & III & Cellular & CN, post-op CT (AVD), RT & $13 \mathrm{~m}$ & Local & $\mathrm{S}, \mathrm{CT}$ (AVD) & Died of tumor progression (1.6y) \\
\hline & Loeb 2002 & $1 \mathrm{y}$ & III & Cellular & $\mathrm{CN}$ (rupture) & $3 \mathrm{~m}$ & Local & CT (AVD), RT & Alive (18y) \\
\hline & \begin{tabular}{|l|} 
Loeb 2002 \\
\end{tabular} & $3 \mathrm{~m}$ & III & Cellular & CN (rupture), post-op CT (AVD) & $5 \mathrm{~m}$ & Local & CT (IFO/CARBO/VP-16), RT & Alive (9y) \\
\hline & \begin{tabular}{|l|} 
Loeb 2002 \\
\end{tabular} & NB & III & Cellular & $\mathrm{CN}$ (rupture) & $5 \mathrm{~m}$ & Local & S, CT (VCD) & Alive $(2 \mathrm{y})$ \\
\hline & \begin{tabular}{|l|} 
Patel 2003 \\
\end{tabular} & $9 \mathrm{~m}$ & II & Cellular & Pre-op CT (AV), CN & $2.5 \mathrm{~m}$ & Liver & CT (VCR/IFO/DOX/VP-16), S & Alive $(1.5 \mathrm{y})$ \\
\hline & Santos 2011 & $2.8 \mathrm{y}$ & NA & Cellular & $\begin{array}{l}\text { S (type unknown), post-op CT } \\
\text { (type NA) }\end{array}$ & $8 \mathrm{~m}$ & Local & S, CT (type NA) & Died of tumor progression $(1.2 \mathrm{y})$ \\
\hline & Steinfeld 1984 & $4 \mathrm{~m}$ & NA & Cellular & $\mathrm{CN}$ & $2 \mathrm{~m}$ & Local, lung & CT (AVD/CYC), RT, S & Alive (1.6y) \\
\hline & Vujanic 1993 & $1.2 \mathrm{y}$ & III & Cellular & $\begin{array}{l}\text { S (type unknown), post-op CT } \\
\text { (AV) }\end{array}$ & $5 \mathrm{~m}$ & Lung, heart & $\mathrm{S}, \mathrm{CT}$ (IFO/VCR) & Died of pneumonia (2y) \\
\hline & Wang 2014 & $1.5 \mathrm{~m}$ & I & Cellular & TE & $8 \mathrm{~m}$ & Local & CT (AVD), S & Alive (4y) \\
\hline & \begin{tabular}{|l|} 
Walker 1973 \\
\end{tabular} & $3 \mathrm{~m}$ & NA & Classic & CN, post-op CT (ACT) & $4 \mathrm{~m}$ & Local & S, RT & Died of tumor progression $(4 \mathrm{~m})$ \\
\hline & Heidelberger 1993 & NB & NA & Mixed & $\mathrm{CN}$ & $7 \mathrm{~m}$ & Brain & S, CT (type NA) & Died of tumor progression $(14 \mathrm{~m})$ \\
\hline & Ko 2013 & NB & III & Mixed & $\mathrm{CN}$ & $7 \mathrm{w}$ & Local, liver & CT (AVC) & Alive $(7 \mathrm{~m})$ \\
\hline & \begin{tabular}{|l|} 
Bell 2002 \\
\end{tabular} & $9 \mathrm{~m}$ & III & Mixed & Pre-op CT, PN, post-op CT & $3 \mathrm{~m}$ & Liver & S, CT (type NA) & NA \\
\hline & \begin{tabular}{|l|} 
Joshi/Fu 1973 \\
\end{tabular} & $1 \mathrm{~d}$ & III & NA & $\mathrm{CN}$ & $4 \mathrm{~m}$ & Local & RT, CT (AV) & Alive $(15 \mathrm{~m})$ \\
\hline
\end{tabular}

Abbreviations ACT: actinomycin, AVC: actinomycin/vincristine/cyclophosphamide, AVD: actinomycin/vincristine/doxorubicin, AVI: actinomycin/vincristine/ifosfamide, CIS : cisplatin, CN: complete nephrectomy, CT: chemotherapy, CYC: cyclophosphamide, DOX: doxorubicin, ICE: ifosfamide/carboplatin/etoposide, ICED:

ifosfamide/cyclophosphamide/etoposide/doxorubicin, IFO: ifosfamide, m: months, NA: not available, NB: newborn, RT: radiotherapy, S: surgery, TE: tumor enucleation, VCD: vincristine/cyclophosphamide/doxorubicin, VCR: vincristine, VP-16: etoposide, y: years 
Supplemental Table S6. Characteristics, treatment and outcome of reported stage III CMN patients

\begin{tabular}{|c|c|c|c|c|c|c|c|c|c|}
\hline $\begin{array}{l}\text { Type of } \\
\text { report }\end{array}$ & Study & Age & Gender & Histology & Initial therapy & $\begin{array}{l}\text { Reason for stage } \\
\text { III }\end{array}$ & Relapse & $\begin{array}{l}\text { Relapse } \\
\text { treatment }\end{array}$ & Outcome \\
\hline \multirow{34}{*}{$\begin{array}{l}\text { Series } \geq 10 \\
\text { patients }\end{array}$} & \begin{tabular}{|l|l|} 
Furtwaengler 2006 \\
\end{tabular} & $3 \mathrm{~m}$ & Female & Cellular & $\mathrm{CN}$ & Tumor rupture & Yes (local) & Surgery, AVD & Alive (5.6y) \\
\hline & Furtwaengler 2006 & $3 \mathrm{~m}$ & Female & Cellular & $\begin{array}{l}\text { PN. } 2^{\text {nd }} \text { look } \\
\text { surgery, CN, post- } \\
\text { op CT }\end{array}$ & $\begin{array}{l}\text { Margin+, tumor } \\
\text { rupture }\end{array}$ & No & - & Alive $(7.2 \mathrm{y})$ \\
\hline & Furtwaengler 2006 & $6 \mathrm{~m}$ & Female & Cellular & $\begin{array}{l}\text { PN. } 2^{\text {nd }} \text { look } \\
\text { surgery, CN }\end{array}$ & $\begin{array}{l}\text { Margin+, tumor } \\
\text { rupture }\end{array}$ & Yes (local) & AVI & DOD (1y) \\
\hline & Furtwaengler 2006 & $8 \mathrm{~m}$ & Female & Cellular & $\begin{array}{l}\mathrm{CN}, 2^{\text {nd }} \text { look } \\
\text { surgery, post-op CT }\end{array}$ & $\begin{array}{l}\text { Margin+, tumor } \\
\text { rupture }\end{array}$ & No & - & Alive (5.8y) \\
\hline & Furtwaengler 2006 & $2 \mathrm{y}$ & Female & Cellular & $\mathrm{CN}$, post-op CT & $\begin{array}{l}\text { Margin+, tumor } \\
\text { rupture }\end{array}$ & No & - & Alive (1.9y) \\
\hline & Bayindir 2009 & $4 \mathrm{~m}$ & Female & Cellular & $\begin{array}{l}\text { Biopsy, pre-op CT } \\
\text { (AV), CN } \\
\text { (incomplete), post- } \\
\text { op CT (AV) }\end{array}$ & Margin + & $\begin{array}{l}\text { Yes (local, } \\
\text { liver) }\end{array}$ & $\begin{array}{l}\text { Surgery, } \\
\text { VCD+VP- } \\
\text { 16/IFO, RT } \\
(10.5 \text { Gy) }\end{array}$ & Alive (7y) \\
\hline & Anderson 2006 & NB & NA & Cellular & $\mathrm{CN}$ & Tumor rupture & Yes (local) & $\begin{array}{l}\text { Surgery, } \\
\text { VCR+ACT+IFO }\end{array}$ & Alive (NA) \\
\hline & Bayindir 2009 & $2 \mathrm{~m}$ & Male & Cellular & CN, post-op CT & Margin+ & No & - & Alive (2.5y) \\
\hline & Bayindir 2009 & $3 \mathrm{~m}$ & Male & Cellular & Biopsy, pre-op CT & Margin+ & No & - & DOD (6m) \\
\hline & England 2011 & NB & NA & Cellular & $\mathrm{CN}$ & $\begin{array}{l}\text { Margin+, tumor } \\
\text { rupture }\end{array}$ & No & - & Alive (4y) \\
\hline & England 2011 & $2 \mathrm{~d}$ & NA & Cellular & $\mathrm{CN}$ & Margin+ & No & - & Alive (1.2y) \\
\hline & Leclair 2005 & NA & NA & Classic & $\mathrm{CN}$ & Tumor rupture & No & - & Alive (2y) \\
\hline & \begin{tabular}{|l|} 
Furtwaengler 2006 \\
\end{tabular} & $\mathrm{NB}$ & Male & Classic & $\mathrm{CN}$ & Margin+ & No & - & Alive (2.2y) \\
\hline & Furtwaengler 2006 & $1 \mathrm{w}$ & Female & Classic & $\mathrm{CN}$ & Margin+ & No & - & Alive (2.7y) \\
\hline & Furtwaengler 2006 & $2 \mathrm{w}$ & Female & Classic & $\mathrm{CN}$ & Margin + & No & - & Alive (2.4y) \\
\hline & Furtwaengler 2006 & $3 \mathrm{~m}$ & Female & Classic & $\begin{array}{l}\mathrm{PN}, 2^{\text {nd }} \text { look } \\
\text { surgery, CN }\end{array}$ & Margin+ & No & - & Alive (1.1y) \\
\hline & \begin{tabular}{|l|} 
England 2011 \\
\end{tabular} & $7 \mathrm{w}$ & NA & Classic & $\mathrm{CN}$ & Margin+ & No & - & Alive (5.3y) \\
\hline & Anderson 2006 & $8 \mathrm{~m}$ & NA & Mixed & $\mathrm{CN}$ & Tumor rupture & Yes (local) & $\begin{array}{l}\text { Surgery. } \\
\text { AVD+ICE }\end{array}$ & Alive (NA) \\
\hline & England 2011 & $1 \mathrm{~d}$ & NA & Mixed & $\mathrm{CN}$ & Margin+ & No & - & Alive $(2.2 \mathrm{y})$ \\
\hline & England 2011 & $2 \mathrm{~d}$ & NA & Mixed & $\mathrm{CN}$ & Margin+ & No & - & Alive (2y) \\
\hline & England 2011 & $11 \mathrm{~m}$ & NA & Mixed & CN, post-op CT & Tumor rupture & No & - & Alive (5.4y) \\
\hline & Howell 1982 & $1 \mathrm{~d}$ & NA & NA & CN, post-op CT & $\begin{array}{l}\text { Margin+, tumor } \\
\text { rupture }\end{array}$ & No & - & Alive (2.5y) \\
\hline & Howell 1982 & $2 \mathrm{~d}$ & NA & NA & CN, post-op CT & $\begin{array}{l}\text { Margin+, tumor } \\
\text { rupture }\end{array}$ & No & - & Alive (6.5y) \\
\hline & Howell 1982 & $2 \mathrm{~d}$ & NA & NA & CN, post-op CT & Tumor rupture & No & - & $\begin{array}{l}\text { Died of sepsis } \\
(2 \mathrm{w})\end{array}$ \\
\hline & Howell 1982 & $3 \mathrm{w}$ & NA & NA & $\mathrm{CN}$ & Tumor rupture & No & - & Alive (1.5y) \\
\hline & \begin{tabular}{|l|l|} 
Howell 1982 \\
\end{tabular} & $3 \mathrm{w}$ & NA & NA & $\mathrm{CN}$ & Tumor rupture & No & - & Alive (1.7y) \\
\hline & Howell 1982 & $1 \mathrm{~m}$ & NA & NA & $\mathrm{CN}$ & $\begin{array}{l}\text { Margin+, tumor } \\
\text { rupture }\end{array}$ & No & - & Alive (2.2y) \\
\hline & Howell 1982 & $4 \mathrm{~m}$ & NA & NA & $\begin{array}{l}\text { CN, post-op CT, } \\
\text { RT }\end{array}$ & $\begin{array}{l}\text { Margin+, tumor } \\
\text { rupture }\end{array}$ & No & - & Alive (2.5y) \\
\hline & Howell 1982 & $4 \mathrm{~m}$ & NA & NA & CN, post-op CT & $\begin{array}{l}\text { Margin+, tumor } \\
\text { rupture }\end{array}$ & No & - & Alive (5.5y) \\
\hline & Howell 1982 & $4 \mathrm{~m}$ & NA & NA & CN, post-op CT & $\begin{array}{l}\text { Margin+, tumor } \\
\text { rupture }\end{array}$ & Yes (local) & $\begin{array}{l}\text { Surgery, } \\
\text { CYC/ADR }\end{array}$ & Alive (2.2y) \\
\hline & \begin{tabular}{|l|} 
Howell 1982 \\
\end{tabular} & $5 \mathrm{~m}$ & NA & NA & CN, post-op CT & Margin+ & No & - & \\
\hline & Howell 1982 & $16 \mathrm{~m}$ & NA & NA & $\begin{array}{l}\text { CN, post-op CT, } \\
\text { RT }\end{array}$ & Margin+ & No & - & \\
\hline & Howell 1982 & $9 \mathrm{y}$ & NA & NA & $\begin{array}{l}\text { CN, post-op CT, } \\
\text { RT }\end{array}$ & Tumor rupture & No & - & \\
\hline & \begin{tabular}{|l} 
Cook 1988/Malone \\
1989 \\
\end{tabular} & $3 d$ & Male & NA & $\mathrm{CN}$, post-op CT & Tumor rupture & No & - & $\begin{array}{l}\text { Died of sepsis } \\
(3 \mathrm{w})\end{array}$ \\
\hline \multirow{3}{*}{\begin{tabular}{|l} 
Case \\
reports
\end{tabular}} & \begin{tabular}{|l|} 
Jayabose 1988 \\
\end{tabular} & $2 \mathrm{~m}$ & Female & Cellular & $\mathrm{CN}, \mathrm{AVD}$ & Margin+ & No & - & Alive (1.8y) \\
\hline & \begin{tabular}{|l|} 
Jones 2007 \\
\end{tabular} & $1 \mathrm{~d}$ & Female & Cellular & $\mathrm{CN}$ & Margin+ & Yes (local) & $\begin{array}{l}\text { Surgery, AVCD } \\
+ \text { cisplatin }\end{array}$ & DOD (1.5y) \\
\hline & Joshi 1986 & $10 \mathrm{~m}$ & Male & Cellular & CN, AVD, RT & Margin+ & Yes (local) & $\begin{array}{l}\text { Surgery, } \\
\text { continuation } \\
\text { AVD }\end{array}$ & DOD (1.5y) \\
\hline
\end{tabular}




\begin{tabular}{|c|c|c|c|c|c|c|c|c|}
\hline Matsumara 1993 & NB & Male & Cellular & $\mathrm{CN}$ & Tumor rupture & No & - & Alive (2y) \\
\hline Jones 2007 & NB & Female & Cellular & $\mathrm{CN}$ & Margin+ & Yes (local) & Surgery & Alive $(7 \mathrm{~m})$ \\
\hline Chan 1995 & $3 d$ & Female & Cellular & $\mathrm{CN}, \mathrm{VCR}$ & Surgical biopsy & No & - & Alive (1y) \\
\hline Gormley 1989 & $2 \mathrm{~m}$ & Female & Cellular & $\mathrm{CN}, \mathrm{AV}$ & Tumor rupture & No & 0 & Alive (9m) \\
\hline Kalidasan 1994 & $5 \mathrm{~m}$ & Male & Cellular & $\mathrm{CN}$ & Tumor rupture & No & - & Alive (7y) \\
\hline Kelly 1985 & $8 \mathrm{~m}$ & Female & Cellular & $\mathrm{CN}, \mathrm{AV}$ & Tumor rupture & No & - & Alive $(11 \mathrm{~m})$ \\
\hline Loeb 2002 & $12 \mathrm{~m}$ & Female & Cellular & $\mathrm{CN}$ & Tumor rupture & Yes (local) & AVD, RT & Alive (18y) \\
\hline Loeb 2002 & $3 \mathrm{~m}$ & Female & Cellular & $\mathrm{CN}, \mathrm{AVD}$ & Tumor rupture & Yes (local) & ICE, RT & Alive (9y) \\
\hline Loeb 2002 & NB & Female & Cellular & $\mathrm{CN}$ & Tumor rupture & Yes (local) & Surgery, VCD & Alive $(2 y)$ \\
\hline McCahon 2003 & NB & Female & Cellular & $\mathrm{AVC}$ & Surgical biopsy & No & - & Alive $(2.5 y)$ \\
\hline Vujanic 1993 & $14 \mathrm{~m}$ & Female & Cellular & $\mathrm{CN}, \mathrm{AV}$ & Margin + & $\begin{array}{l}\text { Yes (lungs, } \\
\text { heart) }\end{array}$ & Surgery, IV & $\begin{array}{l}\text { Died of } \\
\text { pneumonia }(2 y)\end{array}$ \\
\hline \begin{tabular}{|l|} 
Whittle 2010 \\
\end{tabular} & NB & Female & Cellular & $\mathrm{CN}$ & Surgical biopsy & No & - & Alive (1y) \\
\hline Irsutti 2000 & NB & Male & Classic & $\mathrm{CN}$ & Margin+ & No & - & Alive (10m) \\
\hline Walterhouse 1990 & $2 d$ & Male & Classic & $\mathrm{CN}$ & Margin+ & No & - & Alive $(2 \mathrm{y})$ \\
\hline Bell 2002 & $9 \mathrm{~m}$ & Female & Mixed & $\begin{array}{l}\text { Pre-op CT, CN, } \\
\text { post-op CT }\end{array}$ & Margin + & Yes (liver) & $\begin{array}{l}\text { Surgery, CT } \\
\text { (type unknown) }\end{array}$ & \\
\hline Arensman 1980 & $4 \mathrm{~d}$ & Male & NA & $\mathrm{CN}$ & Tumor rupture & No & - & Alive $(2 \mathrm{y})$ \\
\hline Ehman 1983 & NB & Male & NA & $\mathrm{CN}$ & Margin+ & No & - & Alive (1y) \\
\hline Goldberg 1994 & $5 \mathrm{~m}$ & Male & NA & $\mathrm{CN}$ & Tumor rupture & No & - & Alive (1y) \\
\hline Joshi/Fu 1973 & $1 \mathrm{~d}$ & Female & NA & $\mathrm{CN}$ & Margin+ & Yes (local) & Surgery, AV & Alive (12.5y) \\
\hline
\end{tabular}

Abbreviations ADR: adriamycin, AV: actinomcyin/vincristine, AVC: actinomycin/vincristine/cyclophosphamide, AVCD:

actinomycin/vincristine/cyclophosphamide/doxorubicin, AVD: actinomycin/vincristine/doxorubicin, CN: complete nephrectomy, CT:

chemotherapy, CYC: cyclopohspahmide, DOD: died of disease (tumour progression), ICE: ifosfamide/carboplatin/etoposide, IV:

ifosfamide/vincristine, NB: newborn, PN: partial nephrectomy, post-op CT: post-operative chemotherapy, pre-op CT: pre-operative chemotherapy, VCD: vincristine/cyclophosphamide/doxorubicin, VCR: vincristine, VIE: vincristine/ifosfamide/etoposide 